\title{
Albizia Adianthifolia: Botany, Medicinal Uses, Phytochemistry, and Pharmacological Properties
}

\author{
Alfred Maroyi (D) \\ Medicinal Plants and Economic Development (MPED) Research Centre, Department of Botany, University of Fort Hare, \\ Private Bag X1314, Alice 5700, South Africa \\ Correspondence should be addressed to Alfred Maroyi; amaroyi@ufh.ac.za
}

Received 26 June 2018; Accepted 29 August 2018; Published 20 September 2018

Academic Editor: Juei-Tang Cheng

Copyright (C) 2018 Alfred Maroyi. This is an open access article distributed under the Creative Commons Attribution License, which permits unrestricted use, distribution, and reproduction in any medium, provided the original work is properly cited.

The bark, leaves, and roots of Albizia adianthifolia are highly sought after in tropical Africa as herbal medicines. Therefore, the aim of this study was to review the botany, medicinal uses, phytochemistry, and pharmacological properties of A. adianthifolia so as to provide baseline data required for evaluating the therapeutic potential of the species. Information on the botanical profile, medicinal uses, phytochemistry, and pharmacological properties of A. adianthifolia was undertaken using databases such as ScienceDirect, SciFinder, Pubmed, Google Scholar, Medline, SCOPUS, EThOS, ProQuest, OATD, and Open-thesis. Preelectronic literature search of conference papers, scientific articles, books, book chapters, dissertations, and theses was carried out at the University library. Literature search revealed that $A$. adianthifolia is used as purgative and herbal medicine for diabetes, eye problems, gastrointestinal problems, haemorrhoids, headache, neurodegenerative disorders, reproductive problems in women, respiratory problems, wounds and pain, skin diseases, sexually transmitted infections, and ethnoveterinary medicine. Phytochemical compounds identified from the species include apocarotenoids, chalcone, dipeptide, elliptosides, essential oils, fatty acids, flavonoids, histamine, imidazolyl carboxylic acid, prosapogenins, steroids, triterpene saponins, and triterpenoids. Pharmacological studies revealed that A. adianthifolia extracts and compounds have acetylcholinesterase enzyme inhibitory, anthelmintic, antiamoebic, antibacterial, antimycobacterial, anti-sexually transmitted infections, antifungal, anti-inflammatory, antioxidant, anxiolytic, and antidepressant, cognitive-enhancing, haemolytic, hypoglycemic and antihyperglycemic, immunomodulatory, and cytotoxicity activities. Detailed studies on the pharmacokinetics, in vivo, and clinical research involving compounds isolated from A. adianthifolia and extracts of the species are required.

\section{Introduction}

Albizia adianthifolia (Schumach.) W. Wight is a medium to large tree (Figure 1) which belongs to the plant family Fabaceae and subfamily Mimosoideae. The species is a member of Albizia Durazz., a genus that is recognized worldwide for its high ecological, economical, and medicinal value [1]. Albizia species have been used in folk medicine for the treatment of cough, diarrhoea, insomnia, irritability, rheumatism, stomach ache, tuberculosis, and wounds [2]. Phytochemical studies done on different species of Albizia lead to the isolation of different classes of secondary metabolites, such as saponins, terpenes, alkaloids, and flavonoids $[2,3]$. The saponin compounds isolated from the genus Albizia have been reported to possess cancer related activities and other pharmacological properties which include analgesic, anthelmintic, antidysenteric, antihistaminic, anti-inflammatory, antimicrobial, antimutagenic, antiseptic, antispermatogenic, antitumour, anxiolytic, cytotoxic, immunomodulatory, nootropic, and apoptosis inducing properties [3]. According to Louppe et al. (2008) [1], A. adianthifolia is among 13 Albizia species regarded as socially and economically important in tropical Africa as sources of high quality timber, gum, fodder, and herbal medicines. It is, therefore, not surprising that $A$. adianthifolia is considered as one of the most important African medicinal plants by Iwu [4] and, recently, Van Wyk [5] listed the bark of the species as commercially relevant medicinal and aromatic component of herbal medicines in Kenya and South Africa. Albizia adianthifolia is also included in the book "medicinal 


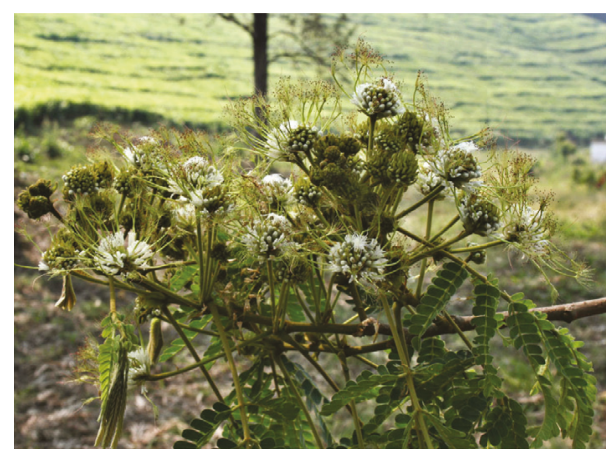

FIgURE 1: Albizia adianthifolia, a branch showing leaves and flowers (photo: MA Hyde).

plants of South Africa", a photographic guide to the most commonly used plant medicines in the country, including their botany, main traditional uses, and active ingredients. Research by Mander [6] showed that A. adianthifolia is ranked among the most frequently demanded medicinal plants in KwaZulu-Natal province in South Africa. Similarly, Williams et al. $(2000,2001)[7,8]$ showed that the bark of the species is commonly traded in medicinal informal markets in Johannesburg, Gauteng province, South Africa. According to Williams et al. (2000) [7], A. adianthifolia was available in more than two-thirds (66\%) of herbal medicine informal markets in Johannesburg. About $9050 \mathrm{~kg}$ to $10400 \mathrm{~kg}$ of $A$. adianthifolia bark were traded per annum as herbal medicine in 2001 in Gauteng province alone [9] and $21200 \mathrm{~kg}$ traded per annum in KwaZulu-Natal province, South Africa [10-12]. Overcollection of $A$. adianthifolia bark as herbal medicine in KwaZulu-Natal province, South Africa, and the trade of its bark in informal herbal medicine markets in the country is causing a population decline and was identified as one of the 15 species becoming increasingly scarce in the province by urban herbalists $[10,13]$. It is within this context that the current study was carried out aimed at reviewing the botany, medicinal uses, phytochemical, and pharmacological properties of $A$. adianthifolia so as to provide baseline data required for evaluating the therapeutic potential of the species.

\section{Research Methodology}

Search for information relevant to the botany, medicinal uses, phytochemical, and pharmacological properties of A. adianthifolia was carried out from October 2017 to May 2018. Online electronic databases including Google Scholar, SciFinder, ScienceDirect, Medline, Pubmed, SCOPUS, EThOS, ProQuest, OATD, and Open-thesis were used to search for relevant literature. Preelectronic literature of conference papers, scientific articles, books, book chapters, dissertations, and theses were carried out at the University of Fort Hare library. The keywords used in the electronic search criteria were "Albizia adianthifolia", synonyms of the plant species “ $A$. chirindensis (Swynn. ex Baker f.) Swynn. ex Steedman, A. ealaensis De Wild., A. fastigiata (E. Mey.) Oliv., A. gummifera auct. non (J. F. Gmel.) C.A. Sm., A. intermedia
De Wild. \& T. Durand, Inga fastigiata (E. Mey.) Oliv., Mimosa adianthifolia Schumach. and Zygia fastigiata E. Mey.", English common names "flat-crown albizia, rough-bark flat-crown albizia and West African albizia". The following keywords were used in combination with the species name, synonyms, and English common names to search for relevant information: "biological properties", "ethnobotany", "ethnomedicinal uses", "ethnopharmacological properties", "medicinal uses", "pharmacological properties", and "phytochemistry". Publications included in this study were published between 1939 and 2018, including 60 articles published in international journals, books (13), conference, working papers and other scientific publications (eight), book chapters (three), dissertation, and website (one each). Three of the research articles were published before 1970, while four were published between 1970 and 1979, 1980 and 1989 (seven articles), 1990 and 1999 (10), 2000 and 2009 (32), and 2010 and 2010 (30 articles).

\section{Botanical Profile and Description of Albizia adianthifolia}

Albizia is a large genus comprising about 120 to 140 species that are widely distributed in tropical Africa (including Madagascar), central South America, south east Asia, and Malaysia [14]. The genus name Albizia was first published by Durazzini in 1772 based on a description of $A$. julibrissin Durazzin grown from seeds imported from Constantinople to Tuscany, Florence, in Italy by Fillippo Degli Albizzi in 1749 [15]. The species name "adianthifolia" refers to the resemblance of the leaves of the species to maidenhair fern, genus Adiantum L., family Pteridaceae [16, 17]. Literature studies revealed the existence of two accepted infraspecifics, A. adianthifolia var. adianthifolia $[18,19]$ and A. adianthifolia var. intermedia (De Wild. \& T. Durand) Villiers [19, 20], and no attempt has been made to provide infraspecific circumscription and geographical distribution of the two varieties. Therefore, A. adianthifolia sensu lato will be used throughout this manuscript. Synonyms of $A$. adianthifolia include $A$. chirindensis, A. ealaensis, A. fastigiata, A. gummifera, A. intermedia, Inga fastigiata, Mimosa adianthifolia, and Zygia fastigiata.

Albizia adianthifolia is a medium to large deciduous tree growing up to $35 \mathrm{~m}$ in height $[16,21]$. The bole is up to 95 $\mathrm{cm}$ in diameter and is straight and cylindrical in closed forest but often crooked and/or twisted in more open savannah and bushland localities, usually without buttresses but with small, thick buttresses in forest localities [16]. The bark is yellowish brown to grey, smooth or rough, inner bark granular, creamy to yellowish in colour with clear gum. Albizia adianthifolia has a flattened crown, with large, spreading branches, young branches densely yellowish or reddish pubescent. Leaves are alternate, bipinnately compound with 3 to 10 pairs of pinnae with ovate to lanceolate stipules and leaflets in 5 to 17 pairs per pinna $[16,21]$. The inflorescence is an axillary head with bisexual small flowers which are reddish to greenish white in colour. The fruit is an oblong, flat pod, densely but finely pubescent, transversely veined, and pale brown 


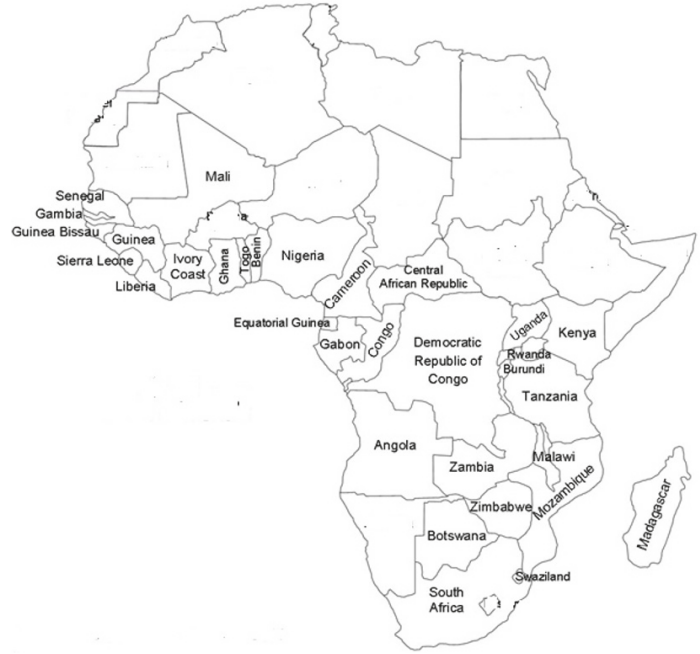

Figure 2: Distribution of Albizia adianthifolia in tropical Africa.

when ripe. The seeds are flattened, swollen, globose in shape and brown in colour [21]. Albizia adianthifolia has been recorded in forests, woodlands, and areas that are transitional to woodland. The species occurs from South Africa through Madagascar, central and east Africa, to Senegal in the north (Figure 2).

The bark of $A$. adianthifolia is one of the most commonly stocked herbal medicine products in the informal herbal medicine markets in South Africa [7-13] and Grace et al. (2003) [22] tried to authenticate dried bark of the species using thin layer chromatography (TLC). This study showed that dried bark of $A$. adianthifolia is often confused with dried bark of Acacia sieberiana DC., Acacia xanthophloea Benth. (family Fabaceae), and Croton sylvaticus Hochst. ex C. Krauss (family Euphorbiaceae), other three plant species sold as herbal medicines in the informal herbal medicine markets in South Africa. Grace et al. [22] argued that the notable similarities in the phytochemical fingerprints of Acacia sieberiana, Acacia xanthophloea, A. adianthifolia, and Croton sylvaticus may be an indicator of close usage relationships as similarities shown by TLC chromatograms may sometimes explain the phytochemical properties common to bark products that are purposefully substituted for one another, particularly in cases where taxonomically unrelated species are used [23].

\section{Medicinal Uses of Albizia adianthifolia}

The bark, leaf sap, leaves, roots, and stem bark of $A$. adianthifolia are used as remedies for human and animal diseases (Table 1). Ethnomedicinal uses of the species have been recorded in Burundi, Cameroon, the Democratic Republic of Congo (DRC), Guinea, Madagascar, Guinea-Bissau, Mozambique, Nigeria, Sierra Leone, Rwanda, Swaziland, South Africa, Tanzania, Uganda, Zimbabwe, and Togo, representing 51.6\% of the countries where the species is indigenous (Figure 3). Major diseases and ailments recorded in at least two countries include diabetes, eye problems, gastrointestinal problems, haemorrhoids, headache, neurodegenerative disorders, purgative, reproductive problems in women, respiratory problems, wounds and pain, skin diseases, sexually transmitted infections, and ethnoveterinary medicine (Figure 3). Albizia adianthifolia is used to manage and treat top three ailments and diseases regarded by the World Health Organization [24] as the leading causes of death in low-income countries, and these are lower respiratory infections, diarrhoeal diseases, and ischaemic heart disease. The bark, leaves, and stem bark of $A$. adianthifolia are used as herbal remedies against bronchitis, cough, respiratory problems, and sinusitis in Cameroon, Mozambique, Nigeria, and South Africa [25-29], which can be categorized as the lower respiratory infections. The bark, leaves, and roots of A. adianthifolia are used as herbal remedies against diarrhoea, dysentery, and stomach ache in the DRC, Madagascar, Mozambique, South Africa, and Tanzania [26, 30-36]. The leaves of $A$. adianthifolia are used as herbal remedies against hypertension in Togo [37], which is one of the most common chronic diseases in modern societies. There is, therefore, a need for further research aimed at correlating some of the ethnomedicinal uses of $A$. adianthifolia to the phytochemical and biological activities of both the crude extracts and chemical compounds isolated from the species. Moreover, the World Health Organization has recognized the important role played by traditional medicines in the provision of primary healthcare in the resource-poor regions like tropical and subtropical Africa [38]. In addition to this, several studies have demonstrated the efficacy and importance of medicinal plants in the development of new pharmaceutical drugs and health products $[39,40]$.

Sexually transmitted infections are treated with multitherapeutic applications involving A. adianthifolia herbal concoctions. For example, in Sierra Leone, stem bark of A. adianthifolia is mixed with fruits of Citrus aurantiifolia (Christm.) Swingle and taken orally as herbal medicine for gonorrhoea [41]. In South Africa, the leaves of A. adianthifolia are mixed with the bark of Trichilia dregeana Sond. and taken orally as herbal medicine for syphilis [42]. In the Democratic Republic of Congo, leaves of A. adianthifolia are mixed with those of Gynura scandens O. Hoffm. and fruits of Musa paradisiaca L. and applied topically as herbal medicine for visible blisters on livestock [43].

\section{Phytochemistry}

To date, about 90 secondary metabolites have been isolated from the heartwood, leaves, roots, root, and stem bark of $A$. adianthifolia. The isolated phytochemical compounds which included apocarotenoids, dipeptide, elliptosides, essential oils, fatty acids, flavonoids, histamines, imidazolyl carboxylic acids, steroids, triterpene saponins, and triterpenoids were identified and characterized using fast atom bombardment mass spectroscopy (FABMS), gas chromatographymass spectrometry (GC-MS), high performance liquid chromatography (HPLC), high-resolution electrospray ionisation mass spectroscopy (HRESIMS), and nuclear magnetic resonance (NMR) techniques (Table 2). The essential oils, fatty acids, triterpene saponins, flavonoids, and phenolics are considered the most prominent family 


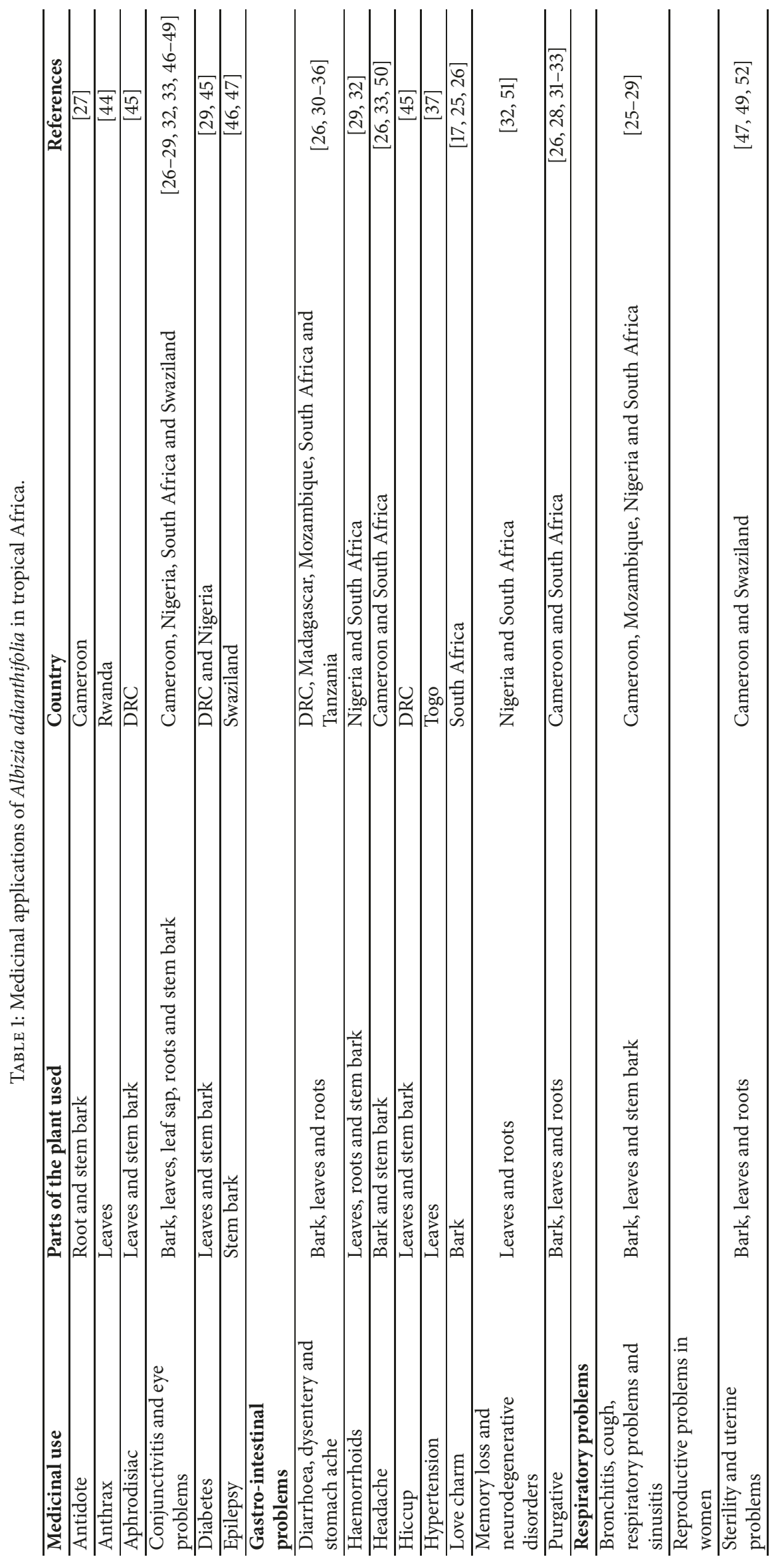




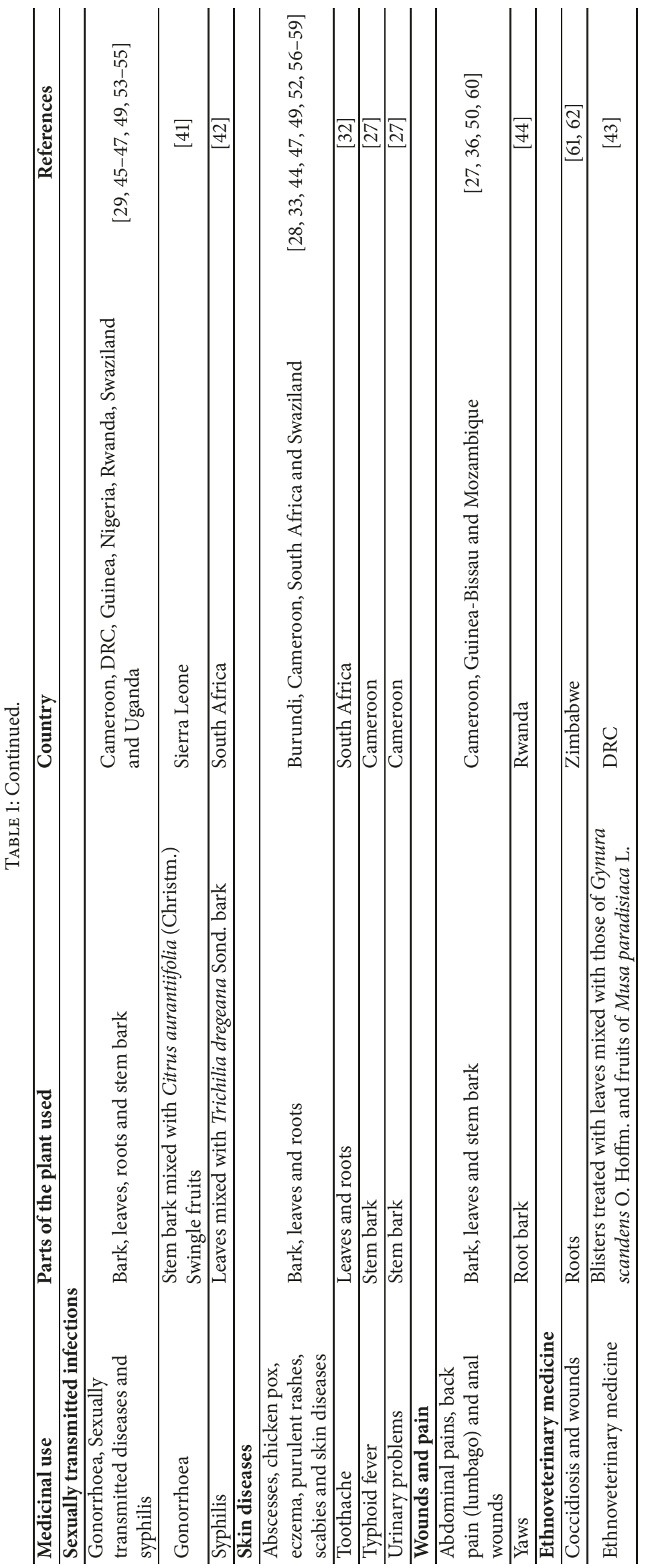


TABLE 2: Phytochemical compounds identified from Albizia adianthifolia.

\begin{tabular}{|c|c|c|c|c|}
\hline No. & Compound & Method of compound analyses & Plant part & References \\
\hline & Apocarotenoids & & & \\
\hline 1 & $\beta$-cyclocitral & GC and GC-MS & Leaves & {$[70]$} \\
\hline 2 & $\beta$-cyclohomocitral & GC and GC-MS & Leaves & {$[70]$} \\
\hline 3 & cis- $\alpha$-ambrinol & GC and GC-MS & Leaves & {$[70]$} \\
\hline 4 & (E)- $\alpha$-ionone & GC and GC-MS & Leaves and stem bark & {$[70]$} \\
\hline 5 & (E)- $\beta$-damascenone & GC and GC-MS & Leaves & {$[70]$} \\
\hline 6 & (E)- $\beta$-ionone & GC and GC-MS & Leaves & {$[70]$} \\
\hline 7 & (E)-geranyl acetone & GC and GC-MS & Leaves & {$[70]$} \\
\hline \multirow[t]{2}{*}{8} & Safranal & GC and GC-MS & Leaves & {$[70]$} \\
\hline & Dipeptide & & & \\
\hline \multirow[t]{2}{*}{9} & Aurantiamide acetate & GC-MS & Stem bark & {$[27]$} \\
\hline & Elliptosides & & & \\
\hline \multirow[t]{3}{*}{10} & Monodesmonoterpenyl elliptoside A & NMR & Roots & [67] \\
\hline & Essential oils & & & \\
\hline & Non-terpene derivatives & & & \\
\hline 11 & 1-octen-3-one & GC and GC-MS & Root bark & {$[70]$} \\
\hline 12 & 1,4-dimethyltetralin & GC and GC-MS & Leaves & {$[70]$} \\
\hline 13 & 1,8-cineole & GC and GC-MS & Leaves, roots and stem bark & {$[70]$} \\
\hline 14 & 2-heptanone & GC and GC-MS & Leaves & {$[70]$} \\
\hline 15 & 2-octanone & GC and GC-MS & Leaves & {$[70]$} \\
\hline 16 & 2-pentadecanone & GC and GC-MS & Root bark & {$[70]$} \\
\hline 17 & 2-phenylethyl butanoate & GC and GC-MS & Root bark & {$[70]$} \\
\hline 18 & 2,4-dimethylbenzaldehyde & GC and GC-MS & Leaves & {$[70]$} \\
\hline 19 & 5-methyltetralin & GC and GC-MS & Leaves & {$[70]$} \\
\hline 20 & 6-methyl-5-hepten-2-one & GC and GC-MS & Leaves & {$[70]$} \\
\hline 21 & $\alpha$-ionone & GC and GC-MS & Leaves & {$[70]$} \\
\hline 22 & Benzaldehyde & GC and GC-MS & Root bark & {$[70]$} \\
\hline 23 & Decanal & GC and GC-MS & Leaves & {$[70]$} \\
\hline 24 & Dehydro-ar-ionene & GC and GC-MS & Leaves & {$[70]$} \\
\hline 25 & Mesitylene & GC and GC-MS & Root bark & {$[70]$} \\
\hline 26 & Naphthalene & GC and GC-MS & Leaves and root bark & {$[70]$} \\
\hline 27 & Nonanal & GC and GC-MS & Leaves & {$[70]$} \\
\hline 28 & Pentadecanal & GC and GC-MS & Leaves, roots and stem bark & {$[70]$} \\
\hline 29 & n-tetradecane & GC and GC-MS & Leaves & {$[70]$} \\
\hline 30 & n-tridecane & GC and GC-MS & Leaves & {$[70]$} \\
\hline 31 & Seudenone & GC and GC-MS & Leaves & {$[70]$} \\
\hline 32 & Tetradecanal & GC and GC-MS & Roots and stem bark & {$[70]$} \\
\hline \multirow[t]{2}{*}{33} & $(\mathrm{Z}, \mathrm{E})$-undeca-1,3,5-triene & GC and GC-MS & Leaves & {$[70]$} \\
\hline & Oxygenated monoterpenes & & & \\
\hline 34 & $\alpha$-terpineol & GC and GC-MS & Leaves & {$[70]$} \\
\hline 35 & Linalool & GC and GC-MS & Leaves and root bark & {$[70]$} \\
\hline 36 & p-menth-4-en-3-one & GC and GC-MS & Leaves & {$[70]$} \\
\hline \multirow[t]{2}{*}{37} & Thymol & GC and GC-MS & Stem bark & {$[70]$} \\
\hline & Oxygenated sesquiterpenes & & & \\
\hline 38 & Acorenone & GC and GC-MS & Leaves and stem bark & {$[70]$} \\
\hline 39 & Caryophylla-4(14),8(15)-dien-5-ol & GC and GC-MS & Leaves and stem bark & {$[70]$} \\
\hline 40 & Caryophyllene oxide & GC and GC-MS & Leaves, roots and stem bark & {$[70]$} \\
\hline 41 & (E)-nerolidol & GC and GC-MS & Leaves and stem bark & {$[70]$} \\
\hline 42 & Humulene epoxide II & GC and GC-MS & Roots and stem bark & {$[70]$} \\
\hline 43 & Occidentalol & GC and GC-MS & Root bark & {$[70]$} \\
\hline
\end{tabular}


TABLE 2: Continued.

\begin{tabular}{|c|c|c|c|c|}
\hline No. & Compound & Method of compound analyses & Plant part & References \\
\hline 44 & Selin-11-en-4- $\alpha$-ol & GC and GC-MS & Roots and stem bark & {$[70]$} \\
\hline 45 & T-cadinol & GC and GC-MS & Leaves and stem bark & {$[70]$} \\
\hline 46 & trans- $\beta$-elemenone & GC and GC-MS & Stem bark & [70] \\
\hline 47 & Valerianol & GC and GC-MS & Root bark & {$[70]$} \\
\hline \multirow[t]{2}{*}{48} & Viridiflorol & GC and GC-MS & Leaves, roots and stem bark & {$[70]$} \\
\hline & Sesquiterpene hydrocarbons & & & \\
\hline 49 & $\alpha$-bulnesene & GC and GC-MS & Stem bark & {$[70]$} \\
\hline 50 & $\alpha$-humulene & GC and GC-MS & Leaves, roots and stem bark & {$[70]$} \\
\hline 51 & ar-curcumene & GC and GC-MS & Leaves and stem bark & {$[70]$} \\
\hline 52 & $\alpha$-zingiberene & GC and GC-MS & Leaves and stem bark & {$[70]$} \\
\hline 53 & $\beta$-bisabolene & GC and GC-MS & Stem bark & {$[70]$} \\
\hline 54 & $\beta$-caryophyllene & GC and GC-MS & Leaves, roots and stem bark & {$[70]$} \\
\hline 55 & $\beta$-elemene & GC and GC-MS & Stem bark & {$[70]$} \\
\hline 56 & $\beta$-sesquiphellandrene & GC and GC-MS & Leaves and stem bark & {$[70]$} \\
\hline 57 & Cyperene & GC and GC-MS & Root bark & {$[70]$} \\
\hline 58 & $\delta$-cadinene & GC and GC-MS & Root bark & {$[70]$} \\
\hline 59 & Isocaryophyllene & GC and GC-MS & Stem bark & {$[70]$} \\
\hline 60 & Italicene & GC and GC-MS & Leaves & {$[70]$} \\
\hline 61 & Sesquisabinene & GC and GC-MS & Stem bark & {$[70]$} \\
\hline 62 & trans- $\gamma$-cadinene & GC and GC-MS & Stem bark & {$[70]$} \\
\hline \multirow[t]{2}{*}{63} & $\gamma$-muurolene & GC and GC-MS & Stem bark & {$[70]$} \\
\hline & Fatty acid & & & \\
\hline 64 & 9,12-octadecadienoic acid (Z,Z)-,methyl ester & GC-MS & Heartwood & [68] \\
\hline 65 & Docosanoic acid & GC-MS & Stem bark & {$[27]$} \\
\hline 66 & n-hexadecanoic acid & GC-MS & Heartwood and stem bark & {$[27,68]$} \\
\hline 67 & Octadecanoic acid & GC-MS & Stem bark & [27] \\
\hline 68 & Oleic acid & GC-MS & Heartwood and stem bark & {$[27,68]$} \\
\hline \multirow[t]{2}{*}{69} & trans-13-octadecanoic acid, methyl ester & GC-MS & Heartwood & {$[68]$} \\
\hline & Flavonoids & & & \\
\hline 70 & 3-methoxyflavanone & MS & Heartwood & {$[64]$} \\
\hline 71 & Apigenin & HPLC & Leaves & {$[28]$} \\
\hline 72 & Chalcone (okanin) & MS & Heartwood & {$[64]$} \\
\hline \multirow[t]{2}{*}{73} & Melanoxetin & MS & Heartwood & {$[64]$} \\
\hline & Steroids & & & \\
\hline 74 & Chondrillasterol & GC-MS & Heartwood & {$[68]$} \\
\hline 75 & Stigmasterol & GC-MS & Heartwood & {$[68]$} \\
\hline \multirow[t]{2}{*}{76} & $24 \mathrm{~S}, 5 \alpha$ stigmast-7-en- $3 \beta$-ol & GC-MS & Heartwood & {$[68]$} \\
\hline & Triterpene saponins & & & \\
\hline 77 & Adianthifoliosides A & FABMS, HRESIMS and NMR & Roots & {$[66]$} \\
\hline 78 & Adianthifoliosides B & FABMS, HRESIMS and NMR & Roots & {$[66]$} \\
\hline 79 & Adianthifoliosides C & NMR & Roots & {$[67]$} \\
\hline 80 & Adianthifoliosides D & NMR & Roots & {$[67]$} \\
\hline 81 & Adianthifoliosides E & NMR & Roots & {$[67]$} \\
\hline 82 & Adianthifoliosides F & NMR & Roots & {$[67]$} \\
\hline 83 & Julibroside A3 & NMR & Roots & {$[65,67]$} \\
\hline 84 & Prosapogenin 1 & FABMS, HRESIMS and NMR & Roots & {$[65,66]$} \\
\hline 85 & Prosapogenin 2 & FABMS, HRESIMS and NMR & Roots & {$[65,66]$} \\
\hline
\end{tabular}


TABLE 2: Continued.

\begin{tabular}{|c|c|c|c|c|}
\hline No. & Compound & Method of compound analyses & Plant part & References \\
\hline & Triterpenoids & & & \\
\hline 86 & Lupeol & GC-MS & Stem bark & [27] \\
\hline \multirow[t]{2}{*}{87} & $3 \beta \mathrm{e}, 16 \beta \mathrm{e}$-dimethoxyolean-12-en-28-21 $\beta$ a-olide & NMR & Root bark & [63] \\
\hline & Histamine & & & \\
\hline 88 & Histamine & GC-MS & Root and stem bark & [71] \\
\hline \multirow[t]{2}{*}{89} & Acetylhistamine & GC-MS & Root and stem bark & [71] \\
\hline & Imidazolyl carboxylic acid & & & \\
\hline 90 & Imidazoleacetic acid & GC-MS & Root and stem bark & [71] \\
\hline
\end{tabular}

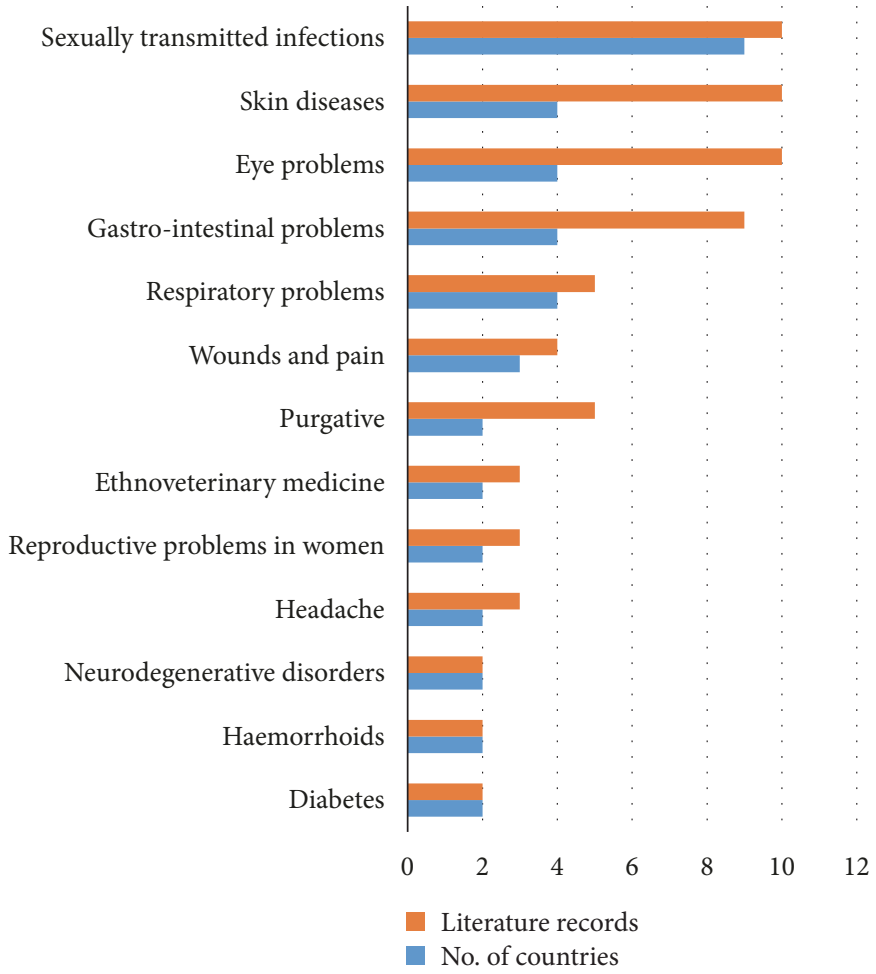

FIgURE 3: Major medicinal uses of Albizia adianthifolia in tropical Africa based on literature records.

of phytochemical compounds occurring in A. adianthifolia [27, 28, 63-71]. Research by Akande et al. (2018) [70] revealed that $\beta$-caryophyllene 54 (23.0\%), E-geranyl acetone $7(7.4 \%)$, acorenone $38(6.4 \%)$, viridiflorol $48(6.4 \%), \alpha$ zingiberene 52 (6.3\%), and ar-curcumene 51 (4.6\%) were the major constituents in the leaf oil, while essential oils $\mathbf{5 4}$ (39.3\%), selin-11-en-4- $\alpha$-ol 44 (10.4\%), 53 (9.6\%), 51 (7.2\%), caryophyllene oxide 40 (6.4\%), and $\alpha$-humulene 50 (5.6\%) were the major constituents in the stem bark oil and essential oils 54 (32.1\%), 44 (13.1\%), 41 (8.4\%), pentadecanal 28 $(6.1 \%)$, and $50(4.4 \%)$ were the major constituents in the root bark oil of $A$. adianthifolia. The gas chromatography-mass spectrometry analyses of n-hexane heartwood extract of $A$. adianthifolia resulted in the identification of $\mathrm{n}$-hexadecanoic acid 66 (34.9\%), stigmasterol $75(28.6 \%)$, oleic acid 68 (6.3\%), 24S, $5 \alpha$ stigmast-7-en-3 $\beta$-ol 76 (4.4\%), and chondrillasterol 74 (18.2\%), while 9,12-octadecadienoic acid (Z,Z), methyl ester 64 (17.6\%), and trans-13-octadecanoic acid, methyl ester $69(37.2 \%)$ were identified from the chloroform extract [68]. Candy et al. (1978) [64] and Beppe et al. (2014) [28] identified flavonoids 3-methoxyflavanone $\mathbf{7 0}$, apigenin $\mathbf{7 1}$, and melanoxetin 72 from the heartwood and leaves of $A$. adianthifolia. Beppe et al. (2014) [28] estimated the total flavonoids in leaves of $A$. adianthifolia to be $0.53 \pm 0.001$ mg rutoside/g lyophilized powder, while the total phenolics in the leaves and stem bark of the species was estimated to be 1.5 to $30.2 \mu \mathrm{g}$ gallic acid equivalents/g dry weight [27, 28, 69]. Roques et al. (1977) [63] and Haddad et al. $(2003,2004)[66,67]$ identified triterpene saponins as major phytochemical compounds in the roots and root bark of $A$. adianthifolia, and these included $16 \alpha$-hydroxy-21 $\beta$-[(2-hydroxybenzoyl)oxy $]-3 \beta-[(\mathrm{O}-\beta-\mathrm{D}$-xylopyranosyl- $(1 \longrightarrow 2)-\mathrm{O}-\beta$ D-fucopyranosyl-(1-6)-2-(acetylamino)-2-deoxy- $\beta$-D-glucopyranosyl)oxy] olean-12-en-28-oic acid 28-O- $\alpha$-L-arabi-

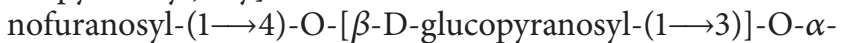
L-rhamnopyranosyl-(1-2)- $\beta$-D-glucopyranosyl ester 77 , 
$16 \alpha$-hydroxy-21 $\beta$-[(2-hydroxybenzoyl)-oxy]-3 $\beta$-[(O- $\beta$-D-

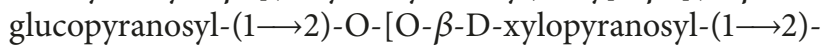
O- $\beta$-D-fucopyranosyl-(1 $\longrightarrow 6$ )]- $\beta$-D-glucopyranosyl)oxy]olean-12-en-28-oic acid 28-O- $\alpha$-L-arabinofuranosyl-( $\longrightarrow$ 4)O-[ $\beta$-D-glucopyranosyl-( $1 \longrightarrow 3)]$-O- $\alpha$-L-rhamnopyranosyl- $(1 \longrightarrow 2) \beta$-D-glucopyranosyl ester 78, 3-O- $\{\mathrm{O}-\alpha$-L-arabinopyranosyl-( $1 \longrightarrow 2)$-O- $\beta$-d-fucopyranosyl- $(1 \longrightarrow 6)-\mathrm{O}-[\beta$-dglucopyranosyl-(1 $\longrightarrow 2)]-\beta$-d-glucopyranosyl $\}-21-\mathrm{O}-\{(2 \mathrm{E}$, $6 \mathrm{~S})-6$ - $\{\{4-\mathrm{O}-[(2 \mathrm{E}, 6 \mathrm{~S})-2,6$-dimethyl-6-( $\beta$-D-quinovopyranosyloxy)octa-2,7-dienoyl]- $\beta$-d-quinovopyranosyl\}oxy\}-2-(hydroxymethyl)-6-methylocta-2,7-dienoyl\}acacic acid 28-\{O$\alpha$-L-arabinofuranosyl-( $(1 \longrightarrow 4)-\mathrm{O}-[\beta$-d-glucopyranosyl- $(1 \longrightarrow$ 3)]-O- $\alpha$-L-rhamnopyranosyl-(1 $\longrightarrow 2)-\beta$-d-glucopyranosyl $\}$ ester 79, 21-O-\{(2E,6S)-6-\{\{4-O-[(2E,6S)-2,6-dimethyl-6- $(\beta$ d-quinovopyranosyloxy)octa-2,7-dienoyl]- $\beta$-d-quinovopyranosyl $\}$ oxy\}-2-(hydroxymethyl)-6-methylocta-2,7-dienoyl\}3 -O- $\{\mathrm{O}-\beta$-D-xylopyranosyl-(1-2)-O- $\beta$-d-fucopyranosyl$(1 \longrightarrow 6)$-2-(acetylamino)-2-deoxy- $\beta$-d-glucopyranosyl $\}$ acacic acid 28-\{O- $\alpha$-L-arabinofuranosyl- $(1 \longrightarrow 4)-\mathrm{O}-[\beta$-d-glucopyranosyl-( $(1 \longrightarrow 3)]$-O- $\alpha$-L-rhamnopyranosyl- $(1 \longrightarrow 2)-\beta$-dglucopyranosyl $\}$ ester 80, 21-O-\{(2E,6S)-6-\{\{3-O-[(2E,6S)2,6-dimethyl-6-( $\beta$-d-quinovopyranosyloxy)octa-2,7-dienoyl]- $\beta$-d-quinovopyranosyl $\}$ oxy $\}$-2,6-dimethylocta-2,7-dienoyl $\}-3-\mathrm{O}-\{\mathrm{O}-\beta$-D-xylopyranosyl-(1-2)-O- $\beta$-d-fucopyranosyl-(1-6)-2-(acetylamino)-2-deoxy- $\beta$-d-glucopyranosyl $\}$ acacic acid $28-\{\mathrm{O}-\alpha$-L-arabinofuranosyl- $(1 \longrightarrow 4)-\mathrm{O}-[\beta$-d-

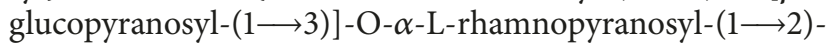
$\beta$-d-glucopyranosyl $\}$ ester 81, and 3-O- $\{\mathrm{O}-\alpha$-L-arabinopy-

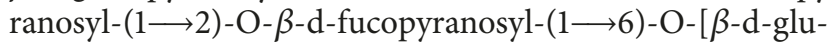

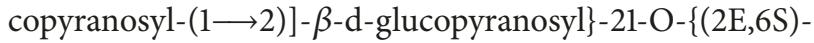
2,6-dimethyl-6-( $\beta$-d-quinovopyranosyloxy)octa-2,7-dienoyl\}acacic acid $28-\{\mathrm{O}-\alpha$-L-arabinofuranosyl- $(1 \longrightarrow 4)-\mathrm{O}-[\beta$-d-

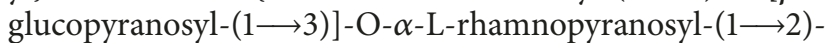
$\beta$-d-glucopyranosyl\} ester $\mathbf{8 2}$ which have been shown to be cytotoxic against a large panel of cancer cells $[3,66]$. Further comprehensive studies focusing on chemical constituents of $A$. adianthifolia and their pharmacological activities are required. Chemical structures of aurantiamide acetate 9, docosanoic acid 65, n-hexadecanoic acid 66, octadecanoic acid 67, oleic acid 68, 16 $\alpha$-hydroxy-21 $\beta$-[(2-hydroxybenzoyl)oxy]-3 $\beta$-[(O- $\beta$-D-xylopyranosyl- $(1 \longrightarrow 2)-\mathrm{O}-\beta$-Dfucopyranosyl-(1 $\longrightarrow 6)-2$-(acetylamino)-2-deoxy- $\beta$-D-glucopyranosyl)oxy] olean-12-en-28-oic acid $28-\mathrm{O}-\alpha$-L-arabino-

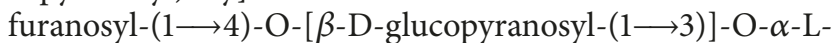
rhamnopyranosyl-(1 $\longrightarrow 2)-\beta$-D-glucopyranosyl ester $77,16 \alpha$ hydroxy-21 $\beta$-[(2-hydroxybenzoyl)-oxy $]-3 \beta$-[(O- $\beta$-D-gluco-

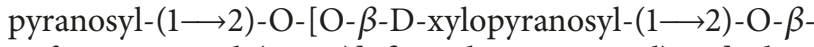
D-fucopyranosyl-(1 $\longrightarrow 6)]-\beta$-D-glucopyranosyl)oxy]-olean12 -en-28-oic acid 28 -O- $\alpha$-L-arabinofuranosyl- $(1 \longrightarrow 4) \mathrm{O}$ - $[\beta$ -

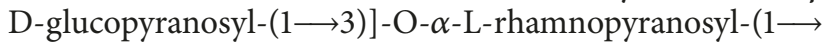
2) $\beta$-D-glucopyranosyl ester $\mathbf{7 8}, 3-\mathrm{O}$ - $\{\mathrm{O}-\alpha$-L-arabinopyrano-

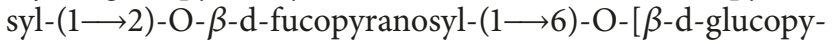
ranosyl- $(1 \longrightarrow 2)]-\beta$-d-glucopyranosyl $\}-21-\mathrm{O}-\{(2 \mathrm{E}, 6 \mathrm{~S})-6-\{\{4-$ O-[(2E,6S)-2,6-dimethyl-6-( $\beta$-D-quinovopyranosyloxy)octa-2,7-dienoyl]- $\beta$-d-quinovopyranosyl\}oxy\}-2-(hydroxymethyl)-6-methylocta-2,7-dienoyl $\}$ acacic acid $28-\{\mathrm{O}-\alpha$-L-arabinofuranosyl-( $(1 \longrightarrow 4)-\mathrm{O}-[\beta$-d-glucopyranosyl-( $(1 \longrightarrow 3)]-\mathrm{O}-$ $\alpha$-L-rhamnopyranosyl-(1 $\longrightarrow 2$ )- $\beta$-d-glucopyranosyl\} ester 79,
21-O-\{(2E,6S)-6-\{\{4-O-[(2E,6S)-2,6-dimethyl-6-( $\beta$-d-quinovopyranosyloxy)octa-2,7-dienoyl]- $\beta$-d-quinovopyranosyl $\}$ oxy\}-2-(hydroxymethyl)-6-methylocta-2,7-dienoyl\}-3-O- $\{\mathrm{O}-$

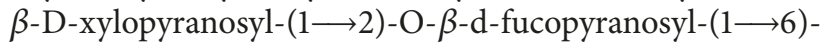
2 -(acetylamino)-2-deoxy- $\beta$-d-glucopyranosyl acacic acid 28$\{\mathrm{O}-\alpha$-L-arabinofuranosyl- $(1 \longrightarrow 4)$-O-[ $\beta$-d-glucopyranosyl$(1 \longrightarrow 3)]-O-\alpha$-L-rhamnopyranosyl-(1 $\longrightarrow 2)$ - $\beta$-d-glucopyranosyl $\}$ ester 80, 21-O- $\{(2 \mathrm{E}, 6 \mathrm{~S})-6$ - $\{\{3-\mathrm{O}-[(2 \mathrm{E}, 6 \mathrm{~S})-2,6$-dimethyl6-( $\beta$-d-quinovopyranosyloxy)octa-2,7-dienoyl]- $\beta$-d-quinovopyranosyl\}oxy\}-2,6-dimethylocta-2,7-dienoyl $\}-3-\mathrm{O}-\{\mathrm{O}-\beta$ -

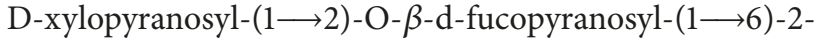
(acetylamino)-2-deoxy- $\beta$-d-glucopyranosyl\}acacic acid 28$\{\mathrm{O}-\alpha$-L-arabinofuranosyl- $(1 \longrightarrow 4)-\mathrm{O}-[\beta$-d-glucopyranosyl$(1 \longrightarrow 3)]$-O- $\alpha$-L-rhamnopyranosyl- $(1 \longrightarrow 2)-\beta$-d-glucopyranosyl $\}$ ester 81 and 3-O-\{O- $\alpha$-L-arabinopyranosyl-(1 $\longrightarrow 2)$ O- $\beta$-d-fucopyranosyl- $(1 \longrightarrow 6)$-O- $[\beta$-d-glucopyranosyl- $(1 \longrightarrow$ 2)]- $\beta$-d-glucopyranosyl $\}-21-\mathrm{O}-\{(2 \mathrm{E}, 6 \mathrm{~S})-2,6$-dimethyl-6- $(\beta$ d-quinovopyranosyloxy)octa-2,7-dienoyl\}acacic acid 28-\{O$\alpha$-L-arabinofuranosyl-(1-4)-O-[ $\beta$-d-glucopyranosyl- $(1 \longrightarrow$ 3)]-O- $\alpha$-L-rhamnopyranosyl-(1 $\longrightarrow 2)-\beta$-d-glucopyranosyl $\}$ ester 82, acacic acid 3-O-beta-D-xylopyranosyl-(1->2)-betaD-fucopyranosyl-(1->6)-2-acetylamino-2-deoxy-beta-D-glucopyranoside 84, acacic acid 3-O-(beta-D-xylopyranosyl(1->2)-beta-D-fucopyranosyl-(1->6)- [beta-D-glucopyranosyl-(1->2)]-beta-D-glucopyranosyl)-21-O-(6(S)-2-hydroxymethyl-6-methyl-6-O-(beta-D-quinovopyranosyl)-2,7-octadienoyl) ester 85, and lupeol 86 which exhibited pharmacological properties [27, 65-68] are shown in Figure 4.

\section{Pharmacological Activities}

Over the years, pharmacological studies on A. adianthifolia extracts and compounds extracted from the species showed potent in vitro and in vivo pharmacological activities including acetylcholinesterase enzyme inhibitory $[69,72,73]$, anthelmintic [70, 74], antiamoebic [74], antibacterial [27, 53, $68,73,75]$, antimycobacterial [76], anti-sexually transmitted infections [77], antifungal [27, 68], anti-inflammatory [73, $78]$, antioxidant $[27,28,69,79,80]$, anxiolytic and antidepressant [79], cognitive-enhancing [28], haemolytic [66, 81], hypoglycemic and antihyperglycemic [45], immunomodulatory [66], cytotoxicity [77, 80-84].

\section{Acetylcholinesterase Enzyme Inhibitory Activities}

Risa et al. (2004) [72] evaluated the acetylcholinesterase inhibiting activities of aqueous and ethanol stem bark extracts of A. adianthifolia using thin layer chromatography (TLC) and microtitre plate assays. The aqueous and ethanol extracts yielded $14 \%$ and $8 \%$ inhibition at $0.1 \mathrm{mg} / \mathrm{ml}$ in the microplate assay and the ethanol extract exhibited weak inhibiting zone in the TLC assay [72]. Eldeen et al. (2005) [73] evaluated acetylcholinesterase enzyme inhibitory activities of ethanol and ethyl acetate bark and root extracts of $A$. adianthifolia using thin layer chromatography (TLC) and microplate assays with galanthamine as the positive control. The extracts exhibited moderate activities with percentage inhibition ranging from $45 \%$ to $61 \%$ and half maximal 

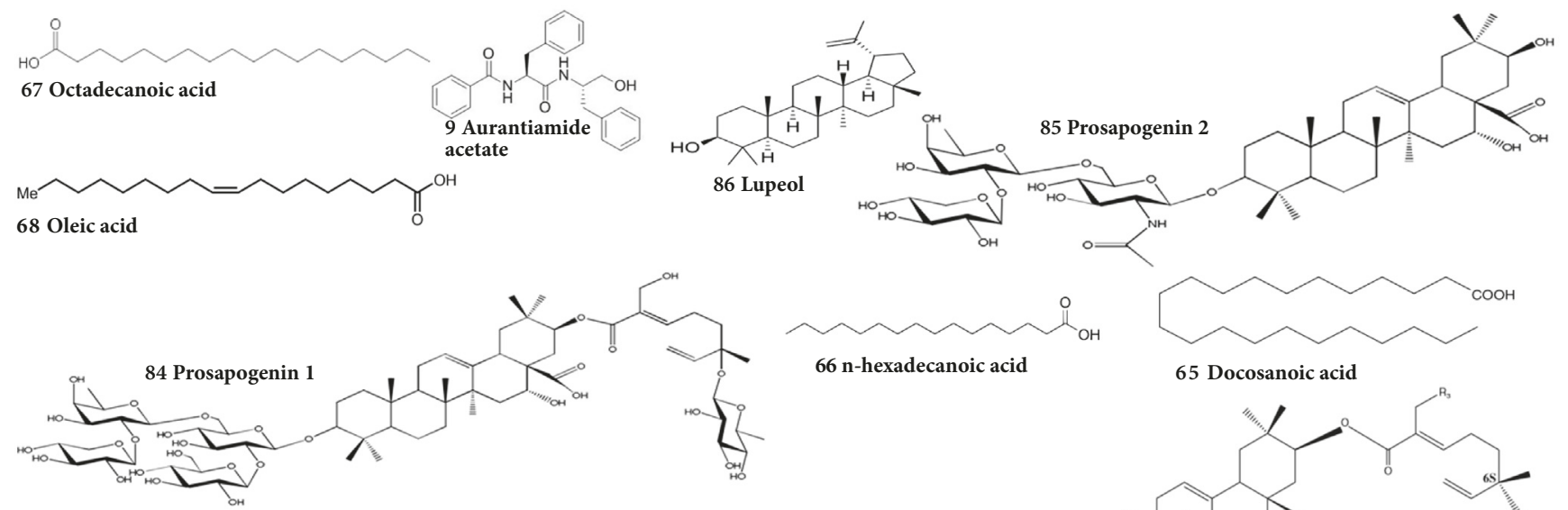

66 -hexadecanoic acid

65 Docosanoic acid

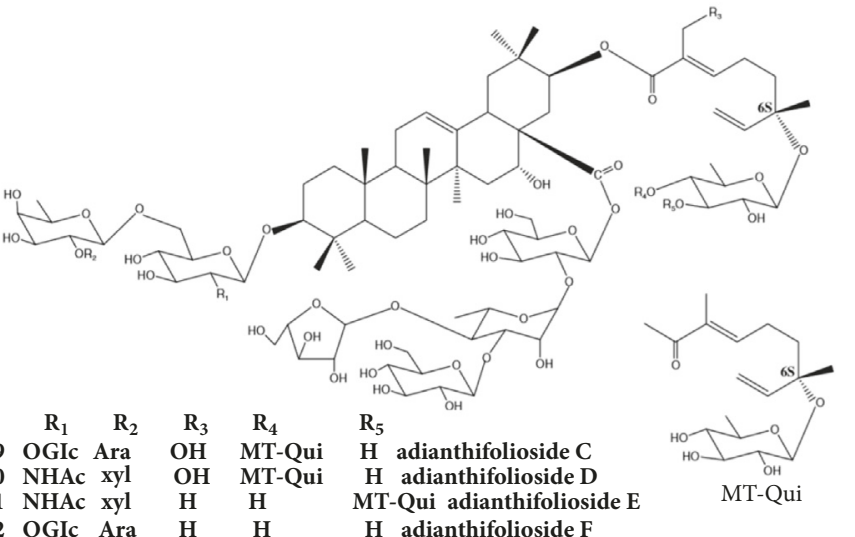

FIGURE 4: Chemical structures of some compounds isolated from Albizia adianthifolia that exhibited pharmacological activities.

inhibitory concentration $\left(\mathrm{IC}_{50}\right)$ values ranging from 0.4 $\mathrm{mg} / \mathrm{ml}$ to $1.2 \mathrm{mg} / \mathrm{ml}$; these values were lower than percentage inhibition of $93 \%$ and $\mathrm{IC}_{50}$ value of $2 \mu \mathrm{M}$ exhibited by the control, galanthamine, at a concentration of $2 \mu \mathrm{M}$ [73]. Sonibare et al. (2017) [69] evaluated the acetylcholinesterase inhibitory activities of methanol, ethyl acetate, chloroform, and n-hexane leaf extracts of $A$. adianthifolia. All extracts showed activities with $\mathrm{IC}_{50}$ values ranging from $10.0 \mu \mathrm{g} / \mathrm{mL}$ to $124.4 \mu \mathrm{g} / \mathrm{mL}$ [69]. The ability of $A$. adianthifolia extracts to inhibit acetylcholinesterase corroborates the traditional use of the species in the management of memory loss and neurodegenerative disorders in South Africa and Nigeria [32, 51].

\section{Anthelmintic Activities}

McGaw et al. (2000) [74] evaluated anthelmintic activities of hexane, ethanol, and water leaf extracts of $A$. adianthifolia on the mortality and reproductive ability of the free-living nematode Caenorhabditis elegans in two different assays. All extracts exhibited activities at both concentrations of $1 \mathrm{mg} / \mathrm{ml}$ and $2 \mathrm{mg} / \mathrm{ml}$ after two-hour and seven-day incubation periods [74]. Akande et al. (2018) [70] evaluated the anthelmintic activities of essential oils isolated from the leaves, root bark, and stem bark of $A$. adianthifolia using Eudrilus eugeniae adult earthworm with albendazole as the standard. The time of paralysis and death of Eudrilus eugeniae worms decreased as concentration was increased. The leaf essential oil showed the best activity with time of paralysis and death at 12.6 minutes and 60.2 minutes, respectively, which was higher than 82.8 minutes and 154.6 minutes exhibited by albendazole, the anthelmintic drug [70].

\section{Antiamoebic Activities}

McGaw et al. (2000) [74] evaluated antiamoebic activities of ethanol and water leaf extracts of $A$. adianthifolia using microdilution technique against the enteropathogenic Entamoeba histolytica with metronidazole as the positive control. The extracts showed weak activities with $\mathrm{IC}_{50}$ value of $>5.0$ $\mathrm{mg} / \mathrm{ml}$ which was higher than $0.20 \mu \mathrm{g} / \mathrm{ml}$ exhibited by metronidazole [74].

\section{Antibacterial Activities}

Van Puyvelde et al. (1983) [53] evaluated antibacterial activities of leaf extracts of $A$. adianthifolia against Neisseria gonorrhoeae, Neisseria meningitidis, Streptococcus pyogenes, and Staphylococcus aureus using the disk diffusion method. The extracts showed activities against Neisseria gonorrhoeae and Neisseria meningitidis with zone of inhibition ranging from $10 \mathrm{~mm}$ to $12 \mathrm{~mm}$ [53]. Eldeen et al. (2005) [73] evaluated antibacterial activities of aqueous, ethanol, and ethyl acetate bark and root extracts of A. adianthifolia against Bacillus subtilis, Staphylococcus aureus, Micrococcus luteus, Escherichia coli, and Klebsiella pneumoniae using the disc-diffusion and microdilution assays with neomycin $(0.2 \mathrm{mg} / \mathrm{ml})$ as the positive control. Ethanol bark extracts were active against 
all tested bacteria with minimum inhibitory concentration (MIC) values ranging from $3.13 \mathrm{mg} / \mathrm{ml}$ to $6.25 \mathrm{mg} / \mathrm{ml}$, while ethyl acetate bark extract was active against all the pathogens except Klebsiella pneumoniae with MIC values ranging from $6.25 \mathrm{mg} / \mathrm{ml}$ to $12.5 \mathrm{mg} / \mathrm{ml}$ [73]. Abubakar and Majinda [68] evaluated antibacterial activities of chloroform and n-hexane extracts of heartwood of A. adianthifolia against Escherichia coli, Pseudomonas aeruginosa, Bacillus subtilis and Staphylococcus aureus using the modified agar overlay method with chloramphenicol as the positive control. The n-hexane and chloroform extracts showed the best activities against Escherichia coli with minimum inhibition quantity (MIQ) of $1 \mu \mathrm{g}$ each while other extracts exhibited moderate activities with MIQ value of $50 \mu \mathrm{g}$ and chloramphenicol exhibited activities with MIQ values ranging from $0.25 \mu \mathrm{g}$ to $10 \mu \mathrm{g}$ [68]. Tchinda et al. (2017) [75] evaluated antibacterial activities of methanol bark and root extracts of $A$. adianthifolia against Pseudomonas aeruginosa, Klebsiella pneumoniae, Enterobacter aerogenes, Escherichia coli, and Providencia stuartii using the broth microdilution assay. The extracts showed moderate to weak activities against tested pathogens with MIC values ranging from $128 \mu \mathrm{g} / \mathrm{mL}$ to $1024 \mu \mathrm{g} / \mathrm{mL}$ [75].

Tamokou et al. (2012) [27] evaluated the antibacterial activities of ethyl acetate extract, aurantiamide acetate $\mathbf{9}$, docosanoic acid $\mathbf{6 5}, \mathrm{n}$-hexadecanoic acid $\mathbf{6 6}$, octadecanoic acid 67, oleic acid 68, and lupeol 86 isolated from the stem bark of $A$. adianthifolia against Enterococcus faecalis, Staphylococcus aureus, Pseudomonas aeruginosa, Escherichia coli, Klebsiella pneumoniae, Proteus mirabilis, Shigella flexneri, and Salmonella typhi using the broth microdilution method with gentamicin as the positive control. The ethyl acetate extract and aurantiamide acetate 9 were active against all the tested pathogens with MIC values ranging from $0.09 \mathrm{mg} / \mathrm{ml}$ to $0.78 \mathrm{mg} / \mathrm{ml}$ and $0.05 \mathrm{mg} / \mathrm{ml}$ to $0.1 \mathrm{mg} / \mathrm{ml}$, respectively [27]. The compound lupeol 86, a mixture of $n$-hexadecanoic acid and oleic acid 68, and a mixture of compounds docosanoic acid 65, n-hexadecanoic acid 66, and octadecanoic acid 67 were active against Enterococcus faecalis, Staphylococcus aureus, Proteus mirabilis, and Shigella flexneri with MIC values ranging from $0.1 \mathrm{mg} / \mathrm{ml}$ to $0.4 \mathrm{mg} / \mathrm{ml}, 0.05 \mathrm{mg} / \mathrm{ml}$ to $0.4 \mathrm{mg} / \mathrm{ml}$, and $0.1 \mathrm{mg} / \mathrm{ml}$ to $0.8 \mathrm{mg} / \mathrm{ml}$, respectively. The exhibited minimum bactericidal concentrations (MBC) were $0.39 \mathrm{mg} / \mathrm{ml}$ to $1.56 \mathrm{mg} / \mathrm{ml}$ for ethyl acetate extract, $0.1 \mathrm{mg} / \mathrm{ml}$ to $0.4 \mathrm{mg} / \mathrm{ml}$ ( $\mathrm{n}$-hexadecanoic acid 66 and oleic acid 68 ), $0.2 \mathrm{mg} / \mathrm{ml}$ to $0.8 \mathrm{mg} / \mathrm{ml}$ (docosanoic acid $65, \mathrm{n}$ hexadecanoic acid 66 and octadecanoic acid 67), $0.2 \mathrm{mg} / \mathrm{ml}$ to $0.4 \mathrm{mg} / \mathrm{ml}$ (compound lupeol 86), and $0.05 \mathrm{mg} / \mathrm{ml}$ to $0.1 \mathrm{mg} / \mathrm{ml}$ (aurantiamide acetate 9) [27]. The documented antibacterial activities exhibited by different extracts and compounds isolated from $A$. adianthifolia corroborate the traditional application of the species as herbal medicine against bacterial infections causing diarrhoea, dysentery, and stomachache in DRC, Madagascar, Mozambique, South Africa, and Tanzania [26, 30-36].

\section{Antimycobacterial Activities}

Eldeen and Van Staden [76] evaluated the antimycobacterial activities of dichloromethane, ethyl acetate, and ethanol bark and leaf extracts of $A$. adianthifolia against Mycobacterium aurum A+ using the broth microdilution method. Only the ethanol root extract exhibited moderate activity with MIC value of $6.3 \mathrm{mg} / \mathrm{ml}$ [76]. These findings show potential of $A$. adianthifolia in the treatment and management of respiratory problems such as bronchitis, cough, and sinusitis in Cameroon, Mozambique, Nigeria, and South Africa [2529].

\section{Anti-Sexually Transmitted Infections Activities}

Naidoo et al. (2013) [77] evaluated anti-sexually transmitted infections activities of aqueous and dichloromethane and methanol (1:1) bark extracts of A. adianthifolia against Candida albicans, Gardnerella vaginalis, Neisseria gonorrhoeae, Oligella ureolytica, Trichomonas vaginalis, and Ureaplasma urealyticum using the microtitre plate dilution method with ciprofloxacin and amphotericin B as positive controls. The anti-sexually transmitted infections interaction of $A$. adianthifolia used in combination with Trichilia dregeana was determined by calculating the sum of the fractional inhibitory concentrations ( $\sum$ FIC) against Oligella ureolytica. The extracts exhibited activities with MIC values ranging from $0.3 \mathrm{mg} / \mathrm{mL}$ to $>16.0 \mathrm{mg} / \mathrm{mL}$ with average MIC value of $6.3 \mathrm{mg} / \mathrm{mL}$ while the controls, ciprofloxacin $(0.01 \mathrm{mg} / \mathrm{mL})$ and amphotericin B $(0.1 \mathrm{mg} / \mathrm{mL})$, exhibited MIC values of $0.04 \mu \mathrm{g} / \mathrm{mL}$ to $0.6 \mu \mathrm{g} / \mathrm{mL}$ and $2.5 \mu \mathrm{g} / \mathrm{mL}$, respectively [77]. The combination of $A$. adianthifolia with Trichilia dregeana resulted in MIC values ranging from $0.8 \mathrm{mg} / \mathrm{mL}$ to $>16.0$ $\mathrm{mg} / \mathrm{mL}$ while $\sum$ FIC values ranged from 0.2 to 0.5 , implying synergistic effects irrespective of the ratio at which these two species were combined, thus supporting the traditional method of mixing the two species as herbal medicine for syphilis in South Africa [42].

\section{Antifungal Activities}

Abubakar and Majinda [68] evaluated antifungal activities of chloroform and n-hexane extracts of heartwood of $A$. adianthifolia against Candida albicans using the modified agar overlay method with miconazole as the positive control. The extracts exhibited weak activities with MIQ value of $>100 \mu \mathrm{g}$ which was much higher than MIQ value of $0.25 \mu \mathrm{g}$ exhibited by miconazole [68]. Similarly, Tamokou et al. (2012) [27] evaluated the antifungal activities of ethyl acetate extract and compounds aurantiamide acetate 9 , docosanoic acid $\mathbf{6 5}$, n-hexadecanoic acid 66, octadecanoic acid 67, oleic acid 68, and lupeol 86 isolated from the stem bark of $A$. adianthifolia against Candida albicans, Candida parapsilosis, Candida lusitaniae, Candida tropicalis, Candida krusei, Candida glabrata, and Cryptococcus neoformans using the broth microdilution method with nystatin as the positive control. The ethyl acetate extract and aurantiamide acetate 9 were active against all the tested pathogens with MIC values ranging from $0.4 \mathrm{mg} / \mathrm{ml}$ to $6.3 \mathrm{mg} / \mathrm{ml}$ and $0.01 \mathrm{mg} / \mathrm{ml}$ to $0.05 \mathrm{mg} / \mathrm{ml}$, respectively [27]. The compound lupeol $\mathbf{8 6}$ was active against Candida albicans, Candida parapsilosis, Candida lusitaniae, Candida krusei, 
and Cryptococcus neoformans with MIC values ranging from $0.1 \mathrm{mg} / \mathrm{ml}$ to $0.4 \mathrm{mg} / \mathrm{ml}$. A mixture of $\mathrm{n}$-hexadecanoic acid 66 and oleic acid 68, and a mixture of docosanoic acid 65, n-hexadecanoic acid 66, and octadecanoic acid 67 were active against Candida albicans, Candida lusitaniae, Candida tropicalis, and Cryptococcus neoformans with MIC values ranging from $0.1 \mathrm{mg} / \mathrm{ml}$ to $0.4 \mathrm{mg} / \mathrm{ml}$. The exhibited minimum fungicidal concentration (MFC) values were 0.8 $\mathrm{mg} / \mathrm{ml}$ to $6.3 \mathrm{mg} / \mathrm{ml}$ for ethyl acetate extract, $0.8 \mathrm{mg} / \mathrm{ml}$ (compounds n-hexadecanoic acid 66 and oleic acid 68), 0.2 $\mathrm{mg} / \mathrm{ml}$ to $0.8 \mathrm{mg} / \mathrm{ml}$ (docosanoic acid $65, \mathrm{n}$-hexadecanoic acid 66 and octadecanoic acid 67), $0.2 \mathrm{mg} / \mathrm{ml}$ to $0.4 \mathrm{mg} / \mathrm{ml}$ (lupeol 86), and $0.006 \mathrm{mg} / \mathrm{ml}$ to $0.05 \mathrm{mg} / \mathrm{ml}$ (aurantiamide acetate 9) [27].

\section{Anti-Inflammatory Activities}

Jäger et al. (1996) [78] evaluated anti-inflammatory activities of aqueous and ethanolic bark extracts of $A$. adianthifolia in an in vitro assay for cyclooxygenase inhibitors with indomethacin $(0.5 \mu \mathrm{g})$ as the control. The ethanolic extract of $A$. adianthifolia showed an inhibition of $69 \%$ which was higher than $66.5 \%$ inhibition exhibited by the indomethacin control. Based on these results, there might be a rationale for the ethnopharmacological claim that A. adianthifolia possess anti-inflammatory properties [78]. Similarly, Eldeen et al. (2005) [73] evaluated anti-inflammatory activities of aqueous, ethanol, and ethyl acetate bark and root extracts of $A$. adianthifolia using the cyclooxygenase (COX-1 and COX-2) assays. Aqueous, ethanol, and ethyl acetate bark and root extracts were active against COX-1 with inhibition percentage ranging from $61 \%$ to $90 \%$ while bark and root ethyl acetate, ethanol, and aqueous bark extracts were active against COX-2 with inhibition percentage ranging from $58 \%$ to $87 \%$ [73]. These finding support the traditional use of $A$. adianthifolia as herbal medicine for abdominal pains, back pain (lumbago), and anal wounds in Cameroon, Guinea-Bissau, and Mozambique [27, 36, 50, 60].

\section{Antioxidant Activities}

Beppe et al. (2014) [28] evaluated the antioxidant activities of aqueous leaf extracts of $A$. adianthifolia using the 1,1diphenyl-2-picrylhydrazyl (DPPH) radical scavenging assay. The DPPH method showed total antioxidant activities of $58.2 \%$ [28]. Sonibare et al. (2017) [69] evaluated the antioxidant activities of methanol, ethyl acetate, chloroform, and n-hexane leaf extracts of $A$. adianthifolia using DPPH free radical scavenging activity assay. All the extracts showed activities with $\mathrm{IC}_{50}$ values ranging from $55.8 \mu \mathrm{g} / \mathrm{mL}$ to 232.2 $\mu \mathrm{g} / \mathrm{mL}$ [69]. Tamokou et al. (2012) [27] evaluated the antioxidant activities of ethyl acetate extract and compounds aurantiamide acetate $\mathbf{9}$ and lupeol $\mathbf{8 6}$ isolated from the stem bark of $A$. adianthifolia using the $\mathrm{DPPH}$ free radical scavenging and trolox equivalent antioxidant capacity (TEAC) assays. Both with the DPPH and TEAC methods, compound 10 showed activities with half maximal effective concentration $\left(\mathrm{EC}_{50}\right)$ value of $9.5 \mu \mathrm{g} / \mathrm{mL}$ and TEAC value of $78.8 \mu \mathrm{g} / \mathrm{mL}$ showed the highest antioxidant activity while ethyl acetate extract exhibited $\mathrm{EC}_{50}$ value of $70.1 \mu \mathrm{g} / \mathrm{mL}$ and TEAC value of $46.7 \mu \mathrm{g} / \mathrm{mL}$ [27]. Beppe et al. (2015) [79] evaluated the antioxidant activity of aqueous leaf extracts of $A$. adianthifolia using superoxide dismutase, glutathione peroxidase and catalase specific activities, the total content of the reduced glutathione, protein carbonyl, and malondialdehyde levels. The increased activities of superoxide dismutase, glutathione peroxidase, catalase, and glutathione level and the decreased levels of protein carbonyl and malondialdehyde induced by administration of the aqueous extract of $A$. adianthifolia leaves implied that this plant extract possesses strong antioxidant property [79]. Sulaiman et al. (2017) [80] evaluated the antioxidant activities of magnetic iron oxide nanoparticles synthesized using $A$. adianthifolia leaf extracts by using the DPPH free radical scavenging assay. The free radical scavenging potential of the magnetic iron oxide nanoparticles was confirmed based on its stable antioxidant effects [80].

\section{Anxiolytic and Antidepressant Activities}

Beppe et al. (2015) [79] evaluated the anxiolytic and antidepressant activities of aqueous leaf extracts of $A$. adianthifolia in the amygdala of 6-hydroxydopamine treated rats model of Parkinson's disease. The extract was administered orally to male Wistar rats at $150 \mathrm{mg} / \mathrm{kg}$ and $300 \mathrm{mg} / \mathrm{kg}$ daily for 21 days and anxiety and depression were assessed using elevated plus-maze and forced swimming tests. Administration of the extract resulted in anxiolytic and antidepressant-like effects which included a decrease of the exploratory activities, the percentage of the time spent, and the number of entries in the open arm within elevated plus-maze tests and decrease of swimming time and increase of immobility time within forced swimming test [79].

\section{Cognitive-Enhancing Activities}

Beppe et al. (2014) [28] evaluated the cognitive-enhancing activities of aqueous leaf extracts of $A$. adianthifolia in the 6-hydroxydopamine-lesion rodent model of Parkinson's disease. The extract was administered orally to male Wistar rats at $150 \mathrm{mg} / \mathrm{kg}$ and $300 \mathrm{mg} / \mathrm{kg}$ daily for 21 days and spatial memory performance was assessed using y-maze and radial arm-maze tasks. The 6-hydroxydopamine-treated rats exhibited a decrease of spontaneous alternations percentage within $y$-maze task and an increase of working memory errors and reference memory errors within radial armmaze task. Administration of the aqueous extract of $A$. adianthifolia leaves significantly improved these parameters, suggesting positive effects on spatial memory formation [28].

\section{Haemolytic Activities}

Haddad et al. (2003) [66] evaluated the haemolytic activities of the crude saponin mixture, compounds 84, 85, 
and $\mathbf{7 8}$ isolated from the roots of A. adianthifolia using the haemolysis assay against sheep erythrocytes. The crude saponin mixture exhibited good haemolytic activities with half maximal haemolytic concentration (HC50) value of $12 \mu \mathrm{g} / \mathrm{mL}$, while compounds $16 \alpha$-hydroxy-21 $\beta$-[(2hydroxybenzoyl)oxy]-3 $\beta$-[(O- $\beta$-D-xylopyranosyl- $(1 \longrightarrow 2)$ O- $\beta$-D-fucopyranosyl-(1 $\longrightarrow 6$ )-2-(acetylamino)-2-deoxy- $\beta$ D-glucopyranosyl)oxy]olean-12-en-28-oic acid 28-O- $\alpha$-L-

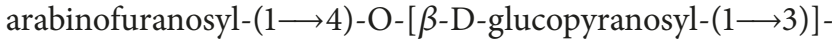
O- $\alpha$-L-rhamnopyranosyl- $(1 \longrightarrow 2)-\beta$-D-glucopyranosyl ester 77 and $16 \alpha$-hydroxy-21 $\beta$-[(2-hydroxybenzoyl)-oxy $]-3 \beta$-[(O$\beta$-D-glucopyranosyl-(1 $\longrightarrow 2)$-O- $[\mathrm{O}-\beta$-D-xylopyranosyl- $(1 \longrightarrow$ 2 )-O- $\beta$-D-fucopyranosyl-(1 $\longrightarrow 6)]-\beta$-D-glucopyranosyl)oxy]olean-12-en-28-oic acid 28-O- $\alpha$-L-arabinofuranosyl-(1 $\longrightarrow$

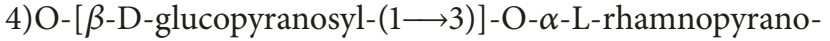
syl- $(1 \longrightarrow 2) \beta$-D-glucopyranosyl ester $\mathbf{7 8}$ exhibited activities with $\mathrm{HD}_{50}$ values of $17.5 \mu \mathrm{g} / \mathrm{mL}$ and $48 \mu \mathrm{g} / \mathrm{mL}$, respectively [66]. Similarly, Haddad et al. [81] evaluated the haemolytic activities of compounds $16 \alpha$-hydroxy-21 $\beta$-[(2-hydroxybenzoyl)oxy]-3 $\beta$-[(O- $\beta$-D-xylopyranosyl-(1 $\longrightarrow 2)-\mathrm{O}-\beta$-D-fuco-

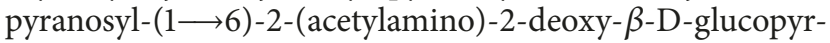
anosyl)oxy] olean-12-en-28-oic acid 28-O- $\alpha$-L-arabinofuran-

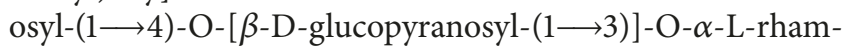
nopyranosyl-(1 $\longrightarrow 2)$ - $\beta$-D-glucopyranosyl ester $77,16 \alpha$-hydroxy-21 $\beta$-[(2-hydroxybenzoyl)-oxy]-3 $\beta$-[(O- $\beta$-D-glucopy-

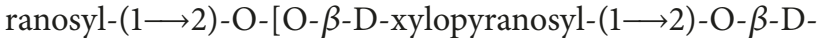
fucopyranosyl-(1-6)]- $\beta$-D-glucopyranosyl)oxy]-olean-12en-28-oic acid $28-\mathrm{O}-\alpha$-L-arabinofuranosyl- $(1 \longrightarrow 4) \mathrm{O}-[\beta$ - $\mathrm{D}$ glucopyranosyl-(1 $\longrightarrow 3)]$-O- $\alpha$-L-rhamnopyranosyl- $(1 \longrightarrow 2) \beta$ D-glucopyranosyl ester 78, and 21-O- $\{(2 \mathrm{E}, 6 \mathrm{~S})-6-\{\{4-\mathrm{O}-[(2 \mathrm{E}$, $6 \mathrm{~S})$-2,6-dimethyl-6-( $\beta$-d-quinovopyranosyloxy)octa-2,7-dienoyl]- $\beta$-d-quinovopyranosyl\}oxy\}-2-(hydroxymethyl)-6methylocta-2,7-dienoyl $\}-3-\mathrm{O}-\{\mathrm{O}-\beta$-D-xylopyranosyl-( $\longrightarrow$

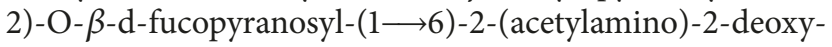
$\beta$-d-glucopyranosyl $\}$ acacic acid $28-\{\mathrm{O}-\alpha$-L-arabinofuranosyl- $(1 \longrightarrow 4)-\mathrm{O}-[\beta$-d-glucopyranosyl- $(1 \longrightarrow 3)]$-O- $\alpha$-L-rhamnopyranosyl-( $1 \longrightarrow 2)$ - $\beta$-d-glucopyranosyl $\}$ ester 80 isolated from the roots of $A$. adianthifolia using the haemolysis assay against sheep erythrocytes. The compounds $16 \alpha$-hydroxy$21 \beta$-[(2-hydroxybenzoyl)oxy]-3 $\beta$-[(O- $\beta$-D-xylopyranosyl-

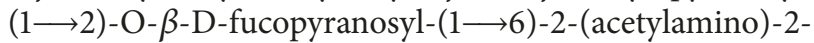
deoxy- $\beta$-D-glucopyranosyl)oxy]olean-12-en-28-oic acid 28$\mathrm{O}-\alpha$-L-arabinofuranosyl-( $1 \longrightarrow 4)$-O-[ $\beta$-D-glucopyranosyl$(1 \longrightarrow 3)]$-O- $\alpha$-L-rhamnopyranosyl-( $1 \longrightarrow 2)$ - $\beta$-D-glucopyranosyl ester $77,16 \alpha$-hydroxy-21 $\beta$-[(2-hydroxybenzoyl)-oxy]$3 \beta$-[(O- $\beta$-D-glucopyranosyl- $(1 \longrightarrow 2)-\mathrm{O}-[\mathrm{O}-\beta$-D-xylopyran-

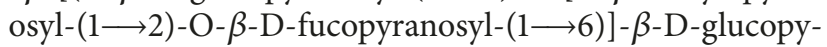
ranosyl)oxy]-olean-12-en-28-oic acid 28-O- $\alpha$-L-arabinofur-

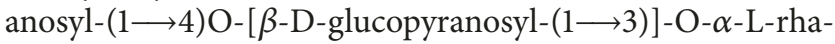
mnopyranosyl- $(1 \longrightarrow 2) \beta$-D-glucopyranosyl ester 78 , and $21-$ $\mathrm{O}-\{(2 \mathrm{E}, 6 \mathrm{~S})-6-\{\{4-\mathrm{O}-[(2 \mathrm{E}, 6 \mathrm{~S})-2,6$-dimethyl-6-( $\beta$-d-quinovopyranosyloxy)octa-2,7-dienoyl]- $\beta$-d-quinovopyranosyl\}oxy\}2-(hydroxymethyl)-6-methylocta-2,7-dienoyl $\}-3-\mathrm{O}-\{\mathrm{O}-\beta-\mathrm{D}-$

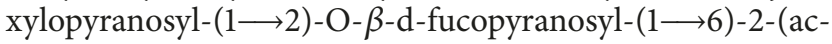
etylamino)-2-deoxy- $\beta$-d-glucopyranosyl $\}$ acacic acid $28-\{\mathrm{O}-$

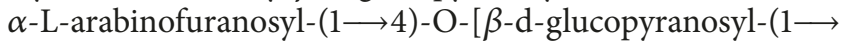
3)]-O- $\alpha$-L-rhamnopyranosyl-(1 $\longrightarrow 2)-\beta$-d-glucopyranosyl $\}$ ester 80 exhibited haemolytic activities with $\mathrm{HC}_{50}$ values ranging from $12.5 \mu \mathrm{g} / \mathrm{mL}$ to $36.6 \mu \mathrm{g} / \mathrm{mL}$ [81].

\section{Hypoglycemic and Antihyperglycemic Activities}

Amuri et al. (2017) [45] evaluated the hypoglycemic and antihyperglycemic activities of leaf extracts of $A$. adianthifolia by administering $500 \mathrm{mg} / \mathrm{kg}$ to guinea pigs (Cavia porcellus), both in glucose baseline conditions and in oral glucose tolerance test with follow-up over 210 minutes. In hypoglycemic tests, the extract induced activities, lowering the normal glycemia by $33 \%$ which was comparable to the activities of the positive control, and glibenclamide $(6 \mathrm{mg} / \mathrm{kg})$ which induced a blood glucose lowering effect of 55\%. In oral glucose tolerance test, the extract was active, causing inhibition of glycemia increase of $57 \%$ which was comparable to the hyperglycemic inhibition rate of glibenclamide of $50 \%$ [45]. These findings support the traditional use of $A$. adianthifolia leaf and stem bark decoction as herbal medicine for diabetes in the DRC [45] and Nigeria [29].

\section{Immunomodulatory Activities}

Haddad et al. (2003) [66] evaluated the immunomodulatory activities of the crude saponin mixture, compounds acacic acid 3-O-beta-D-xylopyranosyl-(1->2)-beta-D-fucopyranosyl-(1->6)- 2-acetylamino-2-deoxy-beta-D-glucopyranoside 84, acacic acid 3-O-(beta-D-xylopyranosyl-(1->2)-beta-Dfucopyranosyl-(1->6)- [beta-D-glucopyranosyl-(1->2)]-betaD-glucopyranosyl)-21-O-(6(S)-2- hydroxymethyl-6-methyl6-O-(beta-D-quinovopyranosyl)-2,7-octadienoyl) ester 85, and $16 \alpha$-hydroxy-21 $\beta$-[(2-hydroxybenzoyl)-oxy $]-3 \beta-[(\mathrm{O}-\beta$ D-glucopyranosyl- $(1 \longrightarrow 2)-\mathrm{O}-[\mathrm{O}-\beta$-D-xylopyranosyl- $(1 \longrightarrow$ 2)-O- $\beta$-D-fucopyranosyl-(1-6)]- $\beta$-D-glucopyranosyl)oxy]olean-12-en-28-oic acid 28-O- $\alpha$-L-arabinofuranosyl-(1 $\longrightarrow$ 4)O-[ $\beta$-D-glucopyranosyl- $(1 \longrightarrow 3)]$-O- $\alpha$-L-rhamnopyranosyl-(1 $\longrightarrow 2) \beta$-D-glucopyranosyl ester $\mathbf{7 8}$ isolated from the roots of $A$. adianthifolia using an in vitro lymphocyte proliferation assay. The cellular proliferation was measured by $3 \mathrm{H}$-thymidine incorporation in Jurkat tumor cell lines (human $\mathrm{T}$ cell leukemia). The compounds acacic acid 3-Obeta-D-xylopyranosyl-(1->2)-beta-D-fucopyranosyl-(1->6)2-acetylamino-2-deoxy-beta-D-glucopyranoside 84 and acacic acid 3-O-(beta-D-xylopyranosyl-(1->2)-beta-D-fucopyranosyl-(1->6)- [beta-D-glucopyranosyl-(1->2)]-beta-D-gluglucopyranosyl)-21-O-(6(S)-2- hydroxymethyl-6-methyl-6O-(beta-D-quinovopyranosyl)-2,7-octadienoyl) ester 85 exhibited a dose-dependent immunomodulatory effect in the concentration range of $0.01 \mu \mathrm{M}$ to $10 \mu \mathrm{M}$, whereas compound $16 \alpha$-hydroxy-21 $\beta$-[(2-hydroxybenzoyl)-oxy $]-3 \beta$ - $[(\mathrm{O}$ $\beta$-D-glucopyranosyl- $(1 \longrightarrow 2)-\mathrm{O}-[\mathrm{O}-\beta$-D-xylopyranosyl- $(1 \longrightarrow$ $2)-O-\beta$-D-fucopyranosyl-(1 $\longrightarrow 6)]-\beta$-D-glucopyranosyl)oxy]olean-12-en-28-oic acid 28-O- $\alpha$-L-arabinofuranosyl- $(1 \longrightarrow$ 4)O-[ $\beta$-D-glucopyranosyl-(1-3)]-O- $\alpha$-L-rhamnopyranosyl-(1 $\longrightarrow 2) \beta$-D-glucopyranosyl ester 78 showed a lymphoproliferative activity in the concentration range of $0.01 \mu \mathrm{M}$ to $10 \mu \mathrm{M}[66]$.

\section{Cytotoxicity Activities}

Naidoo et al. (2013) [77] evaluated cytotoxicity activities of aqueous and dichloromethane and methanol (1:1) bark 
extracts of $A$. adianthifolia using the 3-[4,5-dimethyl-2thiazol-yl]-2,5-diphenyl2H-tetrazolium bromide (MTT) cellular viability assay on the human embryonic kidney epithelial (Graham, HEK-293) cell line. The cell viability assay indicated that the extracts were nontoxic at $100 \mathrm{mg} / \mathrm{ml}$ against the human kidney epithelial cell line, but $110 \%$ and $112 \%$ cell growth exhibited by aqueous and organic extracts, respectively, appeared to increase cellular activity, which would be effective in wound healing [77]. Kuete et al. (2016) [84] evaluated the cytotoxicity activities of methanol bark and root extracts of $A$. adianthifolia against the sensitive leukemia CCRF-CEM cells. The extracts were further tested on a panel of eight human cancer cell lines, including MDR phenotypes. In the preliminary assay using CCRF-CEM cells, the bark and root extracts exhibited activities with $\mathrm{IC}_{50}$ values of $0.98 \mu \mathrm{g} / \mathrm{mL}$ and $1.5 \mu \mathrm{g} / \mathrm{mL}$, respectively. Both bark and root extracts were active against other cell lines and normal AML12 hepatocytes with $\mathrm{IC}_{50}$ values ranging from 2.7 $\mu \mathrm{g} / \mathrm{mL}$ to $10.8 \mu \mathrm{g} / \mathrm{mL}$ towards glioblastoma U87MG. $\Delta \mathrm{EGFR}$ cells, breast adenocarcinoma MDA-MB-231-BCRP cells, and colon carcinoma HCT116( $\mathrm{p}^{-1-} 3^{-/}$) cells. The root extracts induced apoptosis in CCRF-CEM cells through caspases activation and loss of mitochondrial membrane potential [84]. Sulaiman et al. (2017) [80] evaluated the cytotoxic activities of magnetic iron oxide nanoparticles synthesized using $A$. adianthifolia leaf extracts on human breast (AMJ13) and (MCF-7) cancer cells. The observed antiproliferative effects towards AMJ-13 and MCF-7 are due to cell death and inducing apoptosis. Mitochondrial membrane potential and acridine orange-propidium iodide staining assays as well as single cell and DNA gel electrophoresis analyses indicated that magnetic iron oxide nanoparticles induce cell death only by apoptosis [80].

Gengan et al. (2013) [82] evaluated cytotoxic activities of silver nanoparticles (AgNP) synthesized from aqueous leaf extracts of $A$. adianthifolia on the A549 human lung cancer cell line and normal healthy human peripheral lymphocytes using MTT, ATP, and lactate dehydrogenase assays. Viability data for A549 cells showed a $21 \%(10 \mu \mathrm{g} / \mathrm{ml})$ and $73 \%(50 \mu \mathrm{g} / \mathrm{ml})$ cell viability after 6 hours exposure to AgNPs compared to $117 \%(10 \mu \mathrm{g} / \mathrm{ml})$ and $109 \%(50$ $\mu \mathrm{g} / \mathrm{ml}$ ) cell viability of normal peripheral lymphocytes [82]. Govender et al. (2013) [83] evaluated the cytotoxicity activities of silver nanoparticles (AgNP) synthesized from aqueous leaf extracts of A. adianthifolia on A549 lung cells. Cell viability was determined by the MTT assay by determining cellular oxidative status, lipid peroxidation and glutathione levels, ATP concentration, caspase-3/-7, caspase-8, and caspase- 9 activities, apoptosis, mitochondrial membrane depolarization (flow cytometry) and DNA fragmentation, and CD95 receptors, p53, bax, PARP-1, and smac/DIABLO [83]. The silver nanoparticles of $A$. adianthifolia caused a dose-dependent decrease in cell viability with a significant increase in lipid peroxidation, decreased intracellular lipid peroxidation and glutathione, decrease in cellular ATP, elevation in mitochondria depolarization, higher apoptosis, decline in expression of CD95 receptors, reduction in caspase- 8 activity, and increases in caspase-3/-7 and caspase-9 activities; western blots showed increased expression of smac/DIABLO and increased expression of p53, bax, and PARP-1 [83]. Haddad et al. (2004) [81] evaluated the cytotoxic activities of compounds acacic acid 3O-beta-D-xylopyranosyl-(1->2)-beta-D-fucopyranosyl-(1-> 6)-2-acetylamino-2-deoxy-beta-D-glucopyranoside 84 , acacic acid 3-O-(beta-D-xylopyranosyl-(1->2)-beta-D-fucopyranosyl-(1->6)- [beta-D-glucopyranosyl-(1->2)]-beta-D-glucopyranosyl)-21-O-(6(S)-2- hydroxymethyl-6-methyl-6-O(beta-D-quinovopyranosyl)-2,7-octadienoyl) ester 85, 16 $\alpha$ hydroxy-21 $\beta$-[(2-hydroxybenzoyl)oxy $]-3 \beta-[(\mathrm{O}-\beta$-D-xylopyranosyl- $(1 \longrightarrow 2)-O-\beta$-D-fucopyranosyl-(1-6)-2-(acetylamino)-2-deoxy- $\beta$-D-glucopyranosyl)oxy] olean-12-en-28-oic acid 28-O- $\alpha$-L-arabinofuranosyl- $(1 \longrightarrow 4)-\mathrm{O}-[\beta$-D-glucopyranosyl-(1-3)]-O- $\alpha$-L-rhamnopyranosyl- $(1 \longrightarrow 2)-\beta$-D-glucopyranosyl ester 77, 16 $\alpha$-hydroxy-21 $\beta$-[(2-hydroxybenzoyl)-oxy $]-3 \beta$ - $[(\mathrm{O}-\beta$-D-glucopyranosyl- $(1 \longrightarrow 2)-\mathrm{O}-[\mathrm{O}-\beta-\mathrm{D}-$

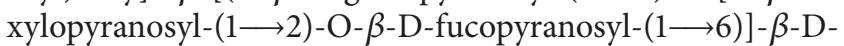
glucopyranosyl)oxy]-olean-12-en-28-oic acid 28-O- $\alpha$-L-arabinofuranosyl- $(1 \longrightarrow 4) \mathrm{O}-[\beta$-D-glucopyranosyl- $(1 \longrightarrow 3)]-\mathrm{O}-$ $\alpha$-L-rhamnopyranosyl-(1-2) $\beta$-D-glucopyranosyl ester 78, and 21-O-\{(2E,6S)-6-\{\{4-O-[(2E,6S)-2,6-dimethyl-6- $(\beta-\mathrm{d}-$ quinovopyranosyloxy)octa-2,7-dienoyl]- $\beta$-d-quinovopyranosyl\} oxy\}-2-(hydroxymethyl)-6-methylocta-2,7-dienoyl $\}$-3$\mathrm{O}$ - $\{\mathrm{O}-\beta$-D-xylopyranosyl-(1-2)-O- $\beta$-d-fucopyranosyl-(1 $\longrightarrow 6)$-2-(acetylamino)-2-deoxy- $\beta$-d-glucopyranosyl $\}$ acacic acid 28- $\{\mathrm{O}-\alpha$-L-arabinofuranosyl-(1 $\longrightarrow 4)-\mathrm{O}-[\beta$-d-glucopyranosyl-(1-3)]-O- $\alpha$-L-rhamnopyranosyl- $(1 \longrightarrow 2)-\beta$-d-glucopyranosyl\} ester $\mathbf{8 0}$ isolated from the roots of $A$. adianthifolia on human leukemia T-cells (Jurkat cells) and on splenocytes. The compounds $16 \alpha$-hydroxy-21 $\beta$-[(2-hydroxybenzoyl)oxy]-3 $\beta$-[(O- $\beta$-D-xylopyranosyl- $(1 \longrightarrow 2)-\mathrm{O}-$ $\beta$-D-fucopyranosyl-(1-6)-2-(acetylamino)-2-deoxy- $\beta$-Dglucopyranosyl)oxy] olean-12-en-28-oic acid 28-O- $\alpha$-L-ara-

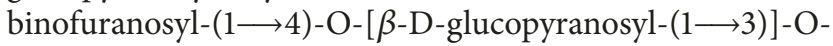
$\alpha$-L-rhamnopyranosyl-(1-2)- $\beta$-D-glucopyranosyl ester 77, $16 \alpha$-hydroxy-21 $\beta$-[(2-hydroxybenzoyl)-oxy $]-3 \beta$ - $[(\mathrm{O}-\beta$-Dglucopyranosyl-(1-2)-O-[O- $\beta$-D-xylopyranosyl- $(1 \longrightarrow 2)$ O- $\beta$-D-fucopyranosyl-(1-6)]- $\beta$-D-glucopyranosyl)oxy]olean-12-en-28-oic acid 28-O- $\alpha$-L-arabinofuranosyl- $(1 \longrightarrow$ 4)O-[ $\beta$-D-glucopyranosyl-(1-3)]-O- $\alpha$-L-rhamnopyranosyl- $(1 \longrightarrow 2) \beta$-D-glucopyranosyl ester 78, and 21-O-\{(2E,6S)6- $\{\{4-\mathrm{O}-[(2 \mathrm{E}, 6 \mathrm{~S})-2,6$-dimethyl-6-( $\beta$-d-quinovopyranosyloxy)octa-2,7-dienoyl]- $\beta$-d-quinovopyranosyl $\}$ oxy $\}$-2-(hydroxymethyl)-6-methylocta-2,7-dienoyl $\}-3-\mathrm{O}-\{\mathrm{O}-\beta$-D-xylopyranosyl- $(1 \longrightarrow 2)-O-\beta$-d-fucopyranosyl- $(1 \longrightarrow 6)$-2-(acetylamino)-2-deoxy- $\beta$-d-glucopyranosyl $\}$ acacic acid $28-\{\mathrm{O}-\alpha$ L-arabinofuranosyl-(1 $\longrightarrow 4)-\mathrm{O}$-[ $\beta$-d-glucopyranosyl- $(1 \longrightarrow$ 3)]-O- $\alpha$-L-rhamnopyranosyl-(1-2)- $\beta$-d-glucopyranosyl $\}$ ester 80 exhibited cytotoxic activities on Jurkat cells, while the compounds acacic acid 3-O-beta-D-xylopyranosyl-(1$>2)$-beta-D-fucopyranosyl-(1->6)-2-acetylamino-2-deoxybeta-D-glucopyranoside 84 and acacic acid 3-O-(beta-Dxylopyranosyl-(1->2)-beta-D-fucopyranosyl-(1->6)- [betaD-glucopyranosyl-(1->2)]-beta-D-glucopyranosyl)-21-O(6(S)-2- hydroxymethyl-6-methyl-6-O-(beta-D-quinovopyranosyl)-2,7-octadienoyl) ester $\mathbf{8 5}$ exhibited lymphoproliferative activities on this cell type. Cytotoxic activity on Jurkat 
cells was observed at $10-1 \mu \mathrm{M}$ and $1 \mu \mathrm{M}$ for compound $21-$ O-\{(2E,6S)-6- $\{\{4-\mathrm{O}-[(2 \mathrm{E}, 6 \mathrm{~S})-2,6-$ dimethyl-6-( $\beta$-d-quinovopyranosyloxy)octa-2,7-dienoyl]- $\beta$-d-quinovopyranosyl\}oxy\}2-(hydroxymethyl)-6-methylocta-2,7-dienoyl $\}-3-\mathrm{O}-\{\mathrm{O}-\beta-\mathrm{D}$ -

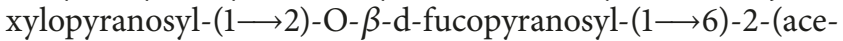
tylamino)-2-deoxy- $\beta$-d-glucopyranosyl $\}$ acacic acid $28-\{\mathrm{O}-\alpha$ -

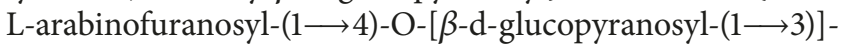
O- $\alpha$-L-rhamnopyranosyl- $(1 \longrightarrow 2)$ - $\beta$-d-glucopyranosyl $\}$ ester 80 and at $1 \mu \mathrm{M}$ for compounds $16 \alpha$-hydroxy-21 $\beta$-[(2-hydroxybenzoyl)oxy $]-3 \beta$-[(O- $\beta$-D-xylopyranosyl- $(1 \longrightarrow 2)-\mathrm{O}-$ $\beta$-D-fucopyranosyl-(1-6)-2-(acetylamino)-2-deoxy- $\beta$-Dglucopyranosyl)oxy]olean-12-en-28-oic acid 28-O- $\alpha$-L-ara-

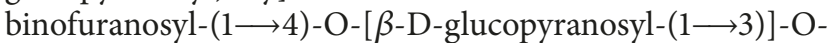
$\alpha$-L-rhamnopyranosyl-(1-2)- $\beta$-D-glucopyranosyl ester 77 and $16 \alpha$-hydroxy-21 $\beta$-[(2-hydroxybenzoyl)-oxy $]-3 \beta-[(\mathrm{O}-\beta$ D-glucopyranosyl-(1-2)-O-[O- $\beta$-D-xylopyranosyl- $(1 \longrightarrow$ 2)-O- $\beta$-D-fucopyranosyl-(1 $\longrightarrow 6)]$ - $\beta$-D-glucopyranosyl)oxy]olean-12-en-28-oic acid 28-O- $\alpha$-L-arabinofuranosyl-(14)O-[ $\beta$-D-glucopyranosyl-(1-3)]-O- $\alpha$-L-rhamnopyranosyl-(1-2) $\beta$-D-glucopyranosyl ester 78 [81].

\section{Conclusion}

Albizia adianthifolia has been used as herbal medicine in tropical Africa for several centuries and significant breakthrough has been made in the last 40 years elucidating the phytochemical and pharmacological properties of the species. However, there are still some research gaps regarding correlating the ethnomedicinal applications of the species with the chemical compounds and pharmacological properties of the compounds and extracts of the species. Detailed studies on the pharmacokinetics, in vivo, and clinical research involving compounds isolated from $A$. adianthifolia and extracts of the species are required. The bark of $A$. adianthifolia is known to be toxic [25] and roots of the species are used as fish poison in Mozambique [85]. Similarly, in southern Cameroon, the gum from the bark of $A$. adianthifolia is used as a hunting poison and in the Central African Republic, the bark and leaves of the species are used as fish poison [86]. These reports highlight the need for detailed toxicological evaluations of both the extracts of the species as well as the compounds isolated from $A$. adianthifolia to establish the toxicity and/or any side effects that can arise when the species and its products are used as herbal medicines.

\section{Conflicts of Interest}

The author declares that there are no conflicts of interest regarding the publication of this paper.

\section{Acknowledgments}

The author would like to express his gratitude to the National Research Foundation (NRF), South Africa, and Govan Mbeki Research and Development Centre (GMRDC), University of Fort Hare, for financial support to conduct this study.

\section{References}

[1] D. Louppe, A. A. Oteng-Amoako, and M. Brink, Plant Resources of Tropical Africa 7: Timbers 1, PROTA Foundation, Backhuys Publishers, Leiden, the Netherlands, 2008.

[2] A. N. Singab, D. Bahgat, E. Al-Sayed, and O. Eldahshan, "Saponins from genus Albizia: phytochemical and biological review," Medicinal and Aromatic Plants, vol. 3, article 1, 2015.

[3] M.-A. Lacaille-Dubois, D. E. Pegnyemb, O. P. Noté, and A.C. Mitaine-Offer, "A review of acacic acid-type saponins from Leguminosae-Mimosoideae as potent cytotoxic and apoptosis inducing agents," Phytochemistry Reviews, vol. 10, no. 4, pp. 565$584,2011$.

[4] M. M. Iwu, Handbook of African Medicinal Plants, CRC Press, Boca Raton, USA, 1993.

[5] B.-E. Van Wyk, "A review of African medicinal and aromatic plants," in Medicinal and Aromatic Plants of the World: Africa, M. Neffati, H. Najjaa, and Á. Máthé, Eds., vol. 3, pp. 19-60, Springer, Dordrecht, The Netherlands, 2017.

[6] M. Mander, Marketing of medicinal plants in South Africa: a case study in KwaZulu-Natal, Food and Agriculture Organization of the United Nations, Rome, Italy, 1998.

[7] V. L. Williams, K. Balkwill, and E. T. F. Witkowski, "Unraveling the commercial market for medicinal plants and plant products on the Witwatersrand, South Africa," Economic Botany, vol. 54, no. 3, pp. 310-337, 2000.

[8] V. L. Williams, K. Balkwill, and E. T. F. Witkowski, "A lexicon of plants traded in the Witwatersrand umuthi shops, South Africa," Bothalia, vol. 31, no. 1, pp. 71-98, 2001.

[9] V. L. Williams, E. T. F. Witkowski, and K. Balkwill, "Volume and financial value of species traded in the medicinal plant markets of Gauteng, South Africa," International Journal of Sustainable Development \& World Ecology, vol. 14, no. 6, pp. 584-603, 2007.

[10] A. B. Cunningham, An investigation of the herbal medicine trade in KwaZulu Natal, Institute of Natural Resources Report 29, Pietermaritzburg, South Africa, 1988.

[11] A. B. Cunningham, African medicinal plants: setting priorities at the interface between conservation and primary health care , People and Plants Working Paper 1, UNESCO, Paris, France, 1993.

[12] B. N. Okole and B. Odhav, "Commercialisation of plants in Africa," South African Journal of Botany, vol. 70, no. 1, pp. 109$115,2004$.

[13] O. M. Grace, H. D. V. Prendergast, J. Van Staden, and A. K. Jäger, "The status of bark in South African traditional health care," South African Journal of Botany, vol. 68, no. 1, pp. 21-30, 2002.

[14] G. P. Lewis and R. L. Arce, "Tribe Ingeae," in Legumes of the World, G. Lewis, B. Schrire, B. Macinker, and M. Lock, Eds., pp. 1-577, Royal Botanic Gardens, Kew, UK, 2005.

[15] I. C. Nielsen, "Notes on the genus Albizia Durazz. (Leguminosae-Mimosoideae) in mainland SE Asia," Adansonia, vol. 19, no. 2, pp. 199-229, 1979.

[16] E. Palmer and P. Pitman, Trees for Southern Africa Covering all Known Indigenous Species in Republic of South Africa, South West Africa, Botswana, Lesotho and Swaziland, A.A. Balkema, Cape Town, South Africa, 1972.

[17] E. Schmidt, M. Lotter, and W. McCleland, Trees and Shrubs of Mpumalanga and Kruger National Park, Jacana Media, Johannesburg, South Africa, 2002.

[18] G. Germishuizen, N. L. Meyer, Y. Steenkamp, and M. Keith, A checklist of South African Plants, Southern African Botanical Diversity Network, Pretoria, South Africa, 2006. 
[19] E. Figueiredo and G. F. Smith, Plants of Angola, Strelitzia 22, South African National Biodiversity Institute, Pretoria, South Africa, 2006.

[20] J.-F. Villiers, “Leguminosae-mimosoideae," Flore de Gabon, vol. 31, pp. 134-158, 1989.

[21] M. C. Palgrave, Keith Coates Palgrave Trees of Southern Africa, Struik Publishers, Cape Town, South Africa, 2002.

[22] O. M. Grace, H. D. V. Prendergast, J. Van Staden, and A. K. Jäger, "The suitability of Thin Layer Chromatography for authenticating bark medicines used in South African traditional healthcare," South African Journal of Botany, vol. 69, no. 2, pp. 165-169, 2003.

[23] A. Maroyi, "Traditional usage, phytochemistry and pharmacology of Croton sylvaticus Hochst. ex C. Krauss," Asian Pacific Journal of Tropical Medicine, vol. 10, no. 5, pp. 423-429, 2017.

[24] World Health Organization (WHO), Fact Sheet, The Top 10 Causes of Death, World Health Organization, Geveva, Switzerland, 2018, http://www.who.int/news-room/fact-sheets/ detail/the-top-10-causes-of-death.

[25] J. M. Watt and M. G. Breyer-Brandwijk, The Medicinal and Poisonous Plants of Southern and Eastern Africa: Pharmacological Effects and Toxicology in Man and Animals, E. Livingstone, Edinburgh, UK, 1962.

[26] J. Pujol, Natur Africa: The Herbalist Handbook, Jean Pujol NaturaJ Healers Foundation, Durban, South Africa, 1990.

[27] J. D. Tamokou, D. J. S. Mpetga, P. K. Lunga, M. Tene, P. Tane, and J. R. Kuiate, "Antioxidant and antimicrobial activities of ethyl acetate extract, fractions and compounds from stem bark of Albizia adianthifolia (Mimosoideae)," BMC Complementary and Alternative Medicine, vol. 12, Article ID 99, 2012.

[28] G. J. Beppe, A. B. Dongmo, H. S. Foyet et al., "Memoryenhancing activities of the aqueous extract of Albizia adianthifolia leaves in the 6-hydroxydopamine-lesion rodent model of Parkinson's disease," BMC Complementary and Alternative Medicine, vol. 14, Article ID 142, 2014.

[29] E. C. Chukwuma, M. O. Soladoye, and R. T. Feyisola, "Traditional medicine and the future of medicinal plants in Nigeria," Journal of Medicinal Plants Studies, vol. 3, no. 4, pp. 23-29, 2015.

[30] J. Gerstner, "A preliminary check list of Zulu names of plants," Bantu Studies, vol. 13, no. 1, pp. 131-149, 1939.

[31] M. D. Jenking, Madagascar: An Environmental Profile, IUCN, Gland, Switzerland, 1987.

[32] D. E. N. Mabogo, The Ethnobotany of the Vhavenda, University of Pretoria, Pretoria, South Africa, 1990.

[33] A. Hutchings, A. H. Scott, G. Lewis, and A. Cunningham, Zulu Medicinal Plants: An Inventory, University of Natal Press, Pietermarizburg, South Africa, 1996.

[34] D. C. Ramathal and O. D. Ngassapa, "Medicinal plants used by Rwandese traditional healers in refugee camps in Tanzania," Pharmaceutical Biology, vol. 39, no. 2, pp. 132-137, 2001.

[35] P. Latham, Useful plants of Bas-Congo province, Democratic Republic of the Congo, Department for International Development, London, UK, 2004.

[36] A. M. Senkoro, F. M. A. Barbosa, S. F. Moiane, G. Albano, and A. I. R. de Barros, "Bark stripping from forest tree species in madjadjane, southern mozambique: medicinal uses and implications for conservation," Natural Resources, vol. 5, no. 5, pp. 192-199, 2014.

[37] H. E. Gbekley, S. D. Karou, G. Katawa et al., "Ethnobotanical survey of medicinal plants used in the management of hypertension in the maritime region of Togo," African Journal of
Traditional Complementary and Alternative Medicine, vol. 15, no. 1, pp. 85-97, 2018.

[38] World Health Organization (WHO), Global Action Plan for The Prevention And Control of Non-Communicable Diseases 20132020, World Health Organization, Geneva, Switzerland, 2013.

[39] A. Gurib-Fakim, "Medicinal plants: traditions of yesterday and drugs of tomorrow," Molecular Aspects of Medicine, vol. 27, no. 1, pp. 1-93, 2006.

[40] G. D. Hughes, O. M. Aboyade, R. Beauclair, O. N. Mbamalu, and T. R. Puoane, "Characterizing Herbal Medicine Use for Noncommunicable Diseases in Urban South Africa," EvidenceBased Complementary and Alternative Medicine, vol. 2015, Article ID 736074, 2015.

[41] A. R. Lebbie and R. P. Guries, "Ethnobotanical value and conservation of sacred groves of the Kpaa Mende in Sierra Leone," Economic Botany, vol. 49, no. 3, pp. 297-308, 1995.

[42] H. de Wet, V. N. Nzama, and S. F. van Vuuren, "Medicinal plants used for the treatment of sexually transmitted infections by lay people in northern Maputaland, KwaZulu-Natal Province, South Africa," South African Journal of Botany, vol. 78, pp. 1220, 2012.

[43] K. Chifundera, "Livestock diseases and the traditional medicine in the Bushi area, Kivu province, Democratic Republic of Congo," African Study Monographs, vol. 19, no. 1, pp. 13-33, 1998.

[44] Y. Boily and L. Van Puyvelde, "Screening of medicinal plants of Rwanda (Central Africa) for antimicrobial activity," Journal of Ethnopharmacology, vol. 16, no. 1, pp. 1-13, 1986.

[45] B. Amuri, M. Maseho, L. Simbi, P. Okusa, P. Duez, and K. Byanga, "Hypoglycemic and antihyperglycemic activities of nine medicinal herbs used as antidiabetic in the region of Lubumbashi (DR Congo)," Phytotherapy Research, vol. 31, no. 7, pp. 1029-1033, 2017.

[46] K. O. Adeniji, O. O. G. Amusan, P. S. Dlamini et al., Traditional Medicine And Pharmacopoeia: Contributions to Ethnobotanical And Floristic Studies in Swaziland, The Scientific, Technical and Research Commission of the Organization of African Unity (OAU/STRC), Swaziland, 1998.

[47] C. Long, Swazilands Flora: siSwati Names And Uses, Swaziland National Trust Commission, Mbambane, Swaziland, 2005, http://www.sntc.org.sz/index.asp.

[48] S. C. Pendota, D. S. Grierson, and A. J. Afolayan, "An ethnobotanical study of plants used for the treatment of eye infections in the Eastern Cape Province, South Africa," Pakistan Journal of Biological Sciences, vol. 11, no. 16, pp. 2051-2053, 2008.

[49] T. Jiofack, I. Ayissi, C. Fokunang, N. Guedje, and V. Kemeuze, "Ethnobotany and phytomedicine of the upper Nyong valley forest in Cameroon," African Journal of Pharmacy and Pharmacology, vol. 3, no. 4, pp. 144-150, 2009.

[50] J. L. Betti, "An ethnobotanical study of medicinal plants among the Baka Pygmies in the Dja biosphere reserve, Cameroon," African Study Monographs, vol. 25, no. 1, pp. 1-27, 2004.

[51] M. A. Sonibare and I. O. Ayoola, "Medicinal plants used in the treatment of neurodegenerative disorders in some parts of Southwest Nigeria," African Journal of Pharmacy and Pharmacology, vol. 9, no. 38, pp. 956-965, 2015.

[52] B. Dlamini, Swaziland Flora: Their Local Names and Uses, Ministry of Agriculture and Cooperatives, Forestry Section, Mbabane, Swaziland, 1981.

[53] L. Van Puyvelde, I. Geiser, P.-C. Rwangabo, and B. Sebikali, "Rwandese herbal remedies used against gonorrhoea," Journal of Ethnopharmacology, vol. 8, no. 3, pp. 279-286, 1983. 
[54] F. B. Magassouba, A. Diallo, M. Kouyaté et al., "Ethnobotanical survey and antibacterial activity of some plants used in Guinean traditional medicine," Journal of Ethnopharmacology, vol. 114, no. 1, pp. 44-53, 2007.

[55] M. Kamatenesi-Mugisha, H. Oryem-Origa, O. Odyek, and D. W. Makawiti, "Medicinal plants used in the treatment of fungal and bacterial infections in and around Queen Elizabeth Biosphere Reserve, western Uganda," African Journal of Ecology, vol. 46, no. s1, pp. 90-97, 2008.

[56] A. T. Bryant, Zulu Medicine and Medicine-Men, C. Struik, Cape Town, South Africa, 1966.

[57] B. M. Corrigan, B.-E. Van Wyk, C. J. Geldenhuys, and J. M. Jardine, "Ethnobotanical plant uses in the KwaNibela Peninsula, St Lucia, South Africa," South African Journal of Botany, vol. 77, no. 2, pp. 346-359, 2011.

[58] B.-E. van Wyk, B. van Oudtshoorn, and N. Gericke, Medicinal Plants of South Africa, Briza Publishers, Pretoria, South Africa, 2013.

[59] J. Ngezahayo, F. Havyarimana, L. Hari, C. Stévigny, and P. Duez, "Medicinal plants used by Burundian traditional healers for the treatment of microbial diseases," Journal of Ethnopharmacology, vol. 173, pp. 338-351, 2015.

[60] L. Catarino, P. J. Havik, and M. M. Romeiras, "Medicinal plants of Guinea-Bissau: Therapeutic applications, ethnic diversity and knowledge transfer," Journal of Ethnopharmacology, vol. 183, pp. 71-94, 2016.

[61] M. Mwale, E. Bhebhe, M. Chimonyo, and T. E. Halimani, "Use of herbal plants in poultry health management in the Mushagashe small-scale commercial farming area in Zimbabwe," International Journal of Applied Research in Veterinary Medicine, vol. 3, no. 2, pp. 163-170, 2005.

[62] G. Gumbochuma, V. R. Hamandishe, E. T. Nyahangare, V. E. Imbayarwo-Chikosi, and S. Ncube, "Ethno veterinary practices for poultry and cattle in Zimbabwe: a case study of Takavarasha village," Scientific Journal of Animal Science, vol. 2, no. 12, pp. 355-359, 2013.

[63] R. Roques, L. Comeau, R. Fourme, R. Khan, and D. André, "Crystal and molecular structure of $3 \beta \mathrm{e}, 16 \beta$-dimethoxy-12(13) oleanane28-21- $\beta$ a-olide," Crystallography and Crystal Chemistry, vol. 33, pp. 1682-1687, 1977.

[64] H. A. Candy, K. B. Brookes, J. R. Bull, E. J. McGarry, and J. M. McGarry, "Flavonoids of Albizia adianthifolia," Phytochemistry, vol. 17, no. 9, pp. 1681-1682, 1978.

[65] M. Haddad, I. A. Khan, and M.-A. Lacaille-Dubois, "Two new prosapogenins from Albizia adianthifolia," Die Pharmazie, vol. 57, no. 10, pp. 705-708, 2002.

[66] M. Haddad, T. Miyamoto, V. Laurens, and M.-A. LacailleDubois, "Two new biologically active triterpenoidal saponins acylated with salicylic acid from Albizia adianthifolia," Journal of Natural Products, American Chemical Society, vol. 66, no. 3, pp. 372-377, 2003.

[67] M. Haddad, T. Miyamoto, and M.-A. Lacaille-Dubois, "New triterpenoidal saponins acylated with monoterpenic acid from Albizia adianthifolia," Helvetica Chimica Acta, vol. 87, no. 5, pp. 1228-1238, 2004.

[68] M. N. Abubakar and R. R. T. Majinda, "GC-MS Analysis and Preliminary Antimicrobial Activity of Albizia adianthifolia (Schumach) and Pterocarpus angolensis (DC)," Medicines, vol. 3, no. 1, Article ID 3, 2016.

[69] M. A. Sonibare, I. O. Ayoola, and T. O. Elufioye, "Antioxidant and acetylcholinesterase inhibitory activities of leaf extract and fractions of Albizia adianthifolia (Schumach) W.F. Wright," Journal of Basic and Clinical Physiology and Pharmacology, vol. 28, no. 2, pp. 143-148, 2017.

[70] A. Akande, S. Aboaba, and G. Flamini, "Constituents and anthelmintic activity evaluation of Albizia adiantifolia (Schumach) W.F. Wright essential oils from Nigeria," International Journal of Chemistry, vol. 10, no. 2, pp. 10-15, 2018.

[71] G. Mazzanti, G. Falconieri Erspamer, Y. Mugne, and D. Piccinelli, "Occurrence of histamine and related imidazole compounds in extracts from root and trunk barks of Albizzia adianthifolia, Albizzia anthelmintica and Albizzia julibrissin," Fitoterapia, vol. 54, no. 6, pp. 275-279, 1983.

[72] A. Risa, J. Risa, A. Adsersen, G. I. Stafford, J. Van Staden, and A. K. Jäger, "Acetylcholinesterase inhibitory activity of plants used as memory-enhancers in traditional South African medicine," South African Journal of Botany, vol. 70, no. 4, pp. 664-666, 2004.

[73] I. M. S. Eldeen, E. E. Elgorashi, and J. Van Staden, "Antibacterial, anti-inflammatory, anti-cholinesterase and mutagenic effects of extracts obtained from some trees used in South African traditional medicine," Journal of Ethnopharmacology, vol. 102, no. 3, pp. 457-464, 2005.

[74] L. J. McGaw, A. K. Jäger, and J. Van Staden, "Antibacterial, anthelmintic and anti-amoebic activity in South African medicinal plants," Journal of Ethnopharmacology, vol. 72, no. 1-2, pp. 247-263, 2000.

[75] C. F. Tchinda, I. K. Voukeng, V. P. Beng, and V. Kuete, "Antibacterial activities of the methanol extracts of Albizia adianthifolia, Alchornea laxiflora, Laportea ovalifolia and three other Cameroonian plants against multi-drug resistant Gramnegative bacteria," Saudi Journal of Biological Sciences, vol. 24, no. 4, pp. 950-955, 2017.

[76] I. M. S. Eldeen and J. Van Staden, "Antimycobacterial activity of some trees used in South African traditional medicine," South African Journal of Botany, vol. 73, no. 2, pp. 248-251, 2007.

[77] D. Naidoo, S. F. Van Vuuren, R. L. Van Zyl, and H. De Wet, "Plants traditionally used individually and in combination to treat sexually transmitted infections in northern Maputaland, South Africa: Antimicrobial activity and cytotoxicity," Journal of Ethnopharmacology, vol. 149, no. 3, pp. 656-667, 2013.

[78] A. K. Jäger, A. Hutchings, and J. Van Staden, "Screening of Zulu medicinal plants for prostaglandin-synthesis inhibitors," Journal of Ethnopharmacology, vol. 52, no. 2, pp. 95-100, 1996.

[79] G. J. Beppe, A. B. Dongmo, H. S. Foyet, T. Dimo, M. Mihasan, and L. Hritcu, "The aqueous extract of Albizia adianthifolia leaves attenuates 6-hydroxydopamine-induced anxiety, depression and oxidative stress in rat amygdala," BMC Complementary and Alternative Medicine, vol. 15, no. 1, article no. 374, 2015.

[80] G. M. Sulaiman, A. T. Tawfeeq, and A. S. Naji, "Biosynthesis, characterization of magnetic iron oxide nanoparticles and evaluations of the cytotoxicity and DNA damage of human breast carcinoma cell lines," Artificial Cells Nanomedicine and Biotechnology, vol. 21, no. 1, pp. 1-15, 2017.

[81] M. Haddad, V. Laurens, and M.-A. Lacaille-Dubois, "Induction of apoptosis in a leukemia cell line by triterpene saponins from Albizia adianthifolia," Bioorganic \& Medicinal Chemistry, vol. 12, no. 17, pp. 4725-4734, 2004.

[82] R. M. Gengan, K. Anand, A. Phulukdaree, and A. Chuturgoon, "A549 lung cell line activity of biosynthesized silver nanoparticles using Albizia adianthifolia leaf," Colloids and Surfaces B: Biointerfaces, vol. 105, pp. 87-91, 2013. 
[83] R. Govender, A. Phulukdaree, R. M. Gengan, K. Anand, and A. A. Chuturgoon, "Silver nanoparticles of Albizia adianthifolia: the induction of apoptosis in human lung carcinoma cell line," Journal of Nanobiotechnology, vol. 11, no. 5, 2013.

[84] V. Kuete, C. F. Tchinda, F. T. Mambe, V. P. Beng, and T. Efferth, "Cytotoxicity of methanol extracts of 10 Cameroonian medicinal plants towards multi-factorial drug-resistant cancer cell lines," BMC Complementary and Alternative Medicine, vol. 16, no. 1, Article ID 267, 2016.

[85] H. D. Neuwinger, "Plants used for poison fishing in tropical Africa," Toxicon, vol. 44, no. 4, pp. 417-430, 2004.

[86] R. H. M. J. Lemmens, “Albizia adianthifolia (Schumach.) W. Wight," in Plant Resources of Tropical Africa 7(1). Timbers 1, D. Louppe, A. A. Oteng-Amoako, and M. Brink, Eds., vol. 1, pp. 40-43, PROTA Foundation, Wageningen, The Netherlands, 1 edition, 2008. 


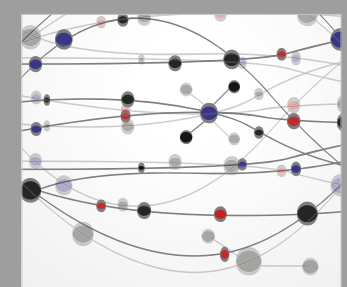

The Scientific World Journal
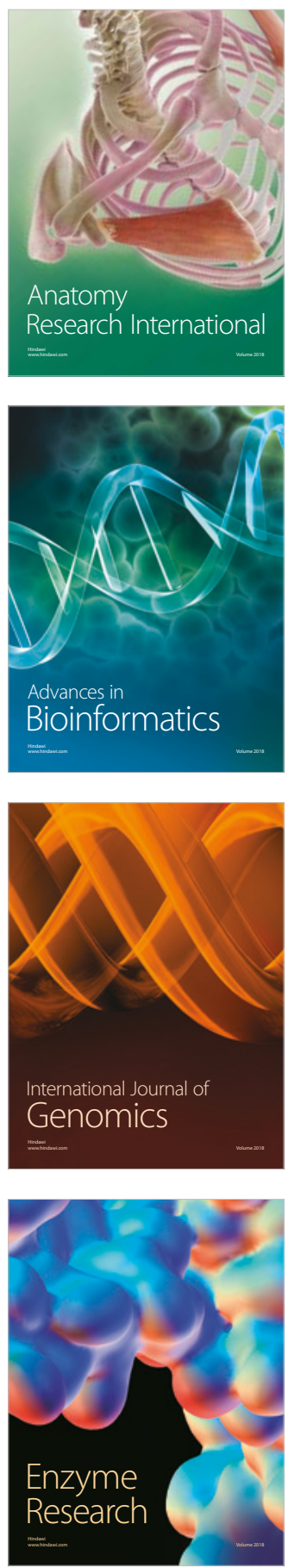
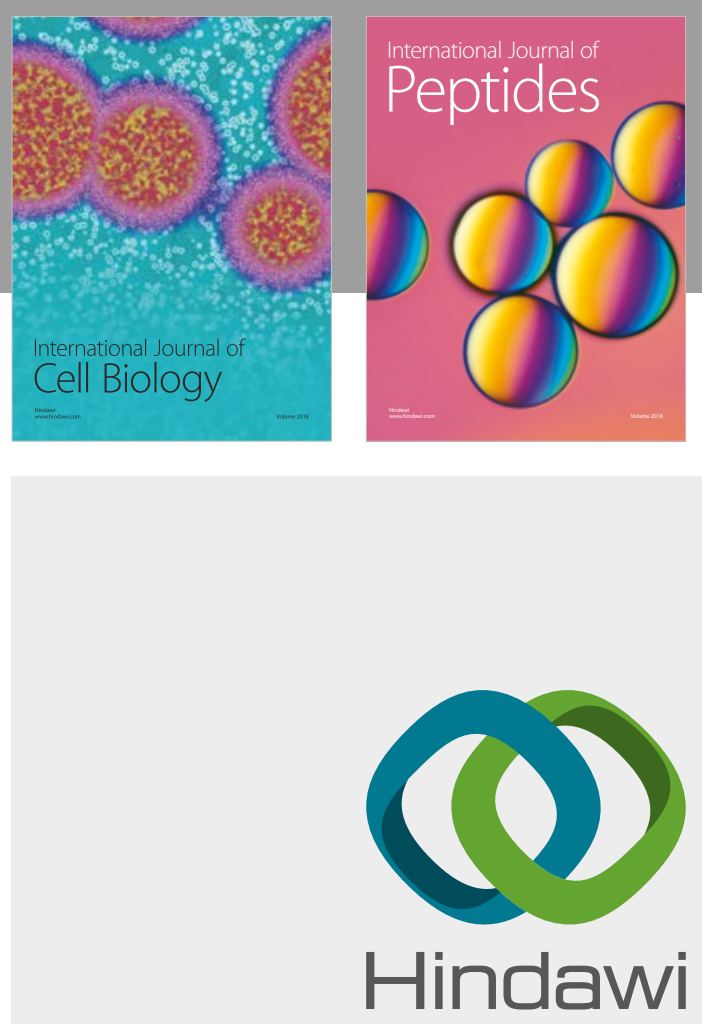

Submit your manuscripts at

www.hindawi.com
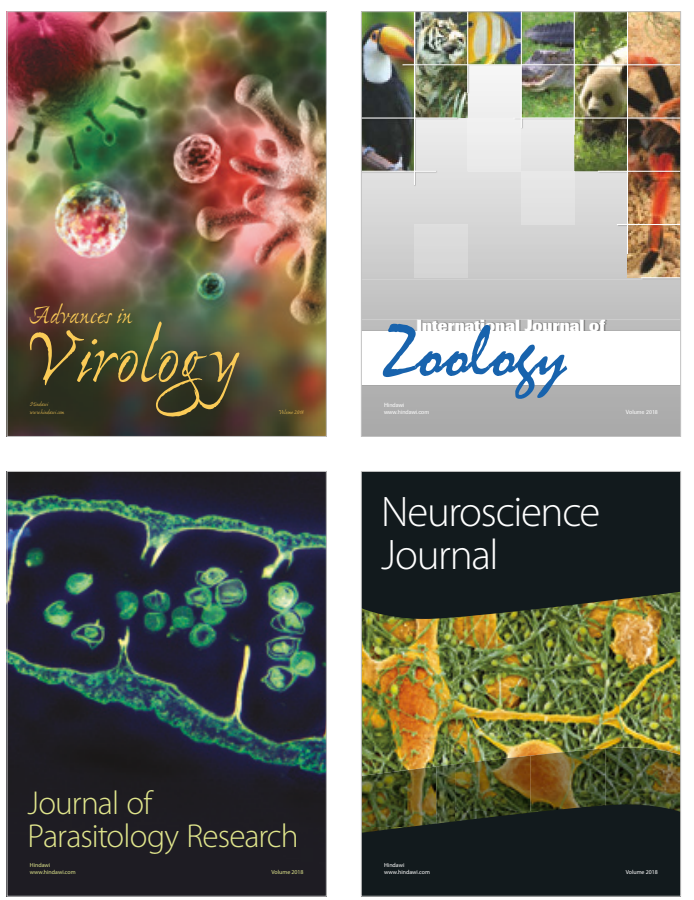
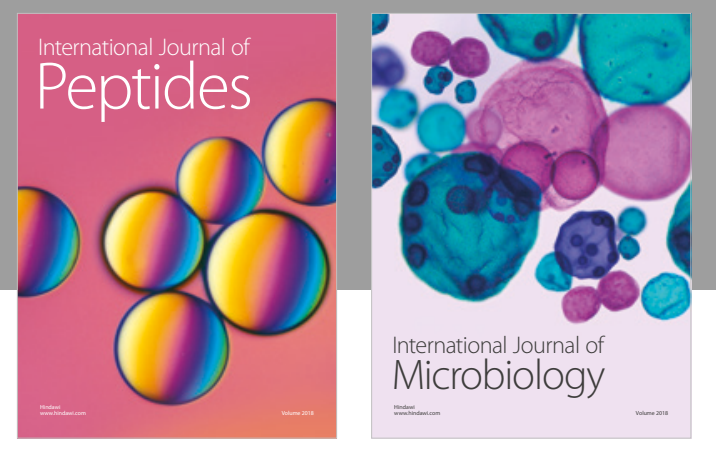

nternational Journal of Microbiology
Journal of
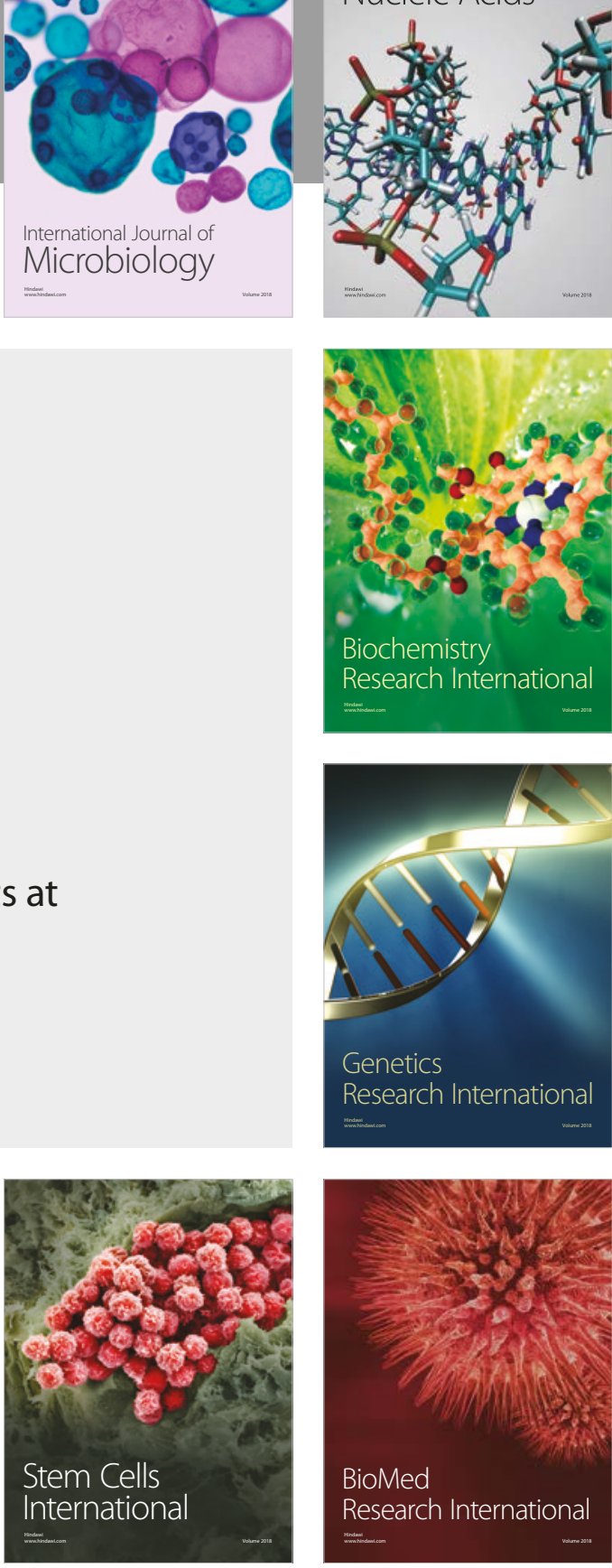
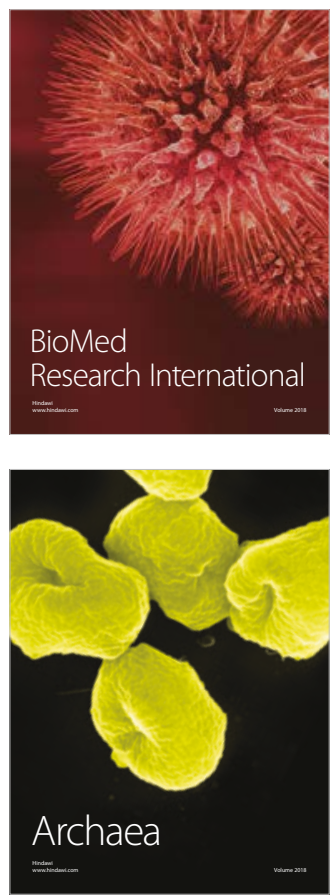